\title{
Late Jurassic to Early Cretaceous black shale formation and paleoenvironment in high northern latitudes: Examples from the Norwegian-Greenland Seaway
}

\author{
Uwe Langrock and Ruediger Stein \\ Alfred Wegener Institute for Polar and Marine Research, Bremerhaven, Germany \\ Marcus Lipinski and Hans-Juergen Brumsack \\ Institute for Chemistry and Biology of the Marine Environment, Oldenburg, Germany \\ Received 25 November 2002; revised 14 February 2003; accepted 14 April 2003; published 19 September 2003.
}

[1] The Late Jurassic to Early Cretaceous (Volgian-Ryazanian) was a period of a second-order sea-level low stand, and it provided excellent conditions for the formation of shallow marine black shales in the NorwegianGreenland Seaway (NGS). IKU Petroleum Research drilling cores taken offshore along the Norwegian shelf were investigated with geochemical and microscopic approaches to (1) determine the composition of the organic matter, (2) characterize the depositional environments, and (3) discuss the mechanisms which may have controlled production, accumulation, and preservation of the organic matter. The black shale sequences show a wide range of organic carbon contents $(0.5-7.0 \mathrm{wt} \%)$ and consist of thermally immature organic matter of type II to II/III kerogen. Rock-Eval pyrolysis revealed fair to very good petroleum source rock potential, suggesting a deposition in restricted shallow marine basins. Well-developed lamination and the formation of autochthonous pyrite framboids further indicate suboxic to anoxic bottom water conditions. In combination with very low sedimentation rates it seems likely that preservation was the principal control on organic matter accumulation. However, a decrease of organic carbon preservation and an increase of refractory organic matter from the Volgian to the Hauterivian are superimposed on short-term variations (probably reflecting Milankovitch cycles). Various parameters indicate that black shale formation in the NGS was gradually terminated by increased oxidative conditions in the course of a sea-level rise. INDEX TERMS: 1055 Geochemistry: Organic geochemistry; 4802 Oceanography: Biological and Chemical: Anoxic environments; 9609 Information Related to Geologic Time: Mesozoic; 8105 Tectonophysics: Continental margins and sedimentary basins (1212); KEYWORDS: black shale formation, depositional environment, Norwegian-Greenland Seaway, Mesozoic, organic petrography

Citation: Langrock, U., R. Stein, M. Lipinski, and H.-J. Brumsack, Late Jurassic to Early Cretaceous black shale formation and paleoenvironment in high northern latitudes: Examples from the Norwegian-Greenland Seaway, Paleoceanography, 18(3), 1074, doi:10.1029/2002PA000867, 2003.

\section{Introduction}

[2] High primary production of coastal waters, a stratified water column, anoxic bottom waters, low influx of clastic material (low dilution), and high supply of terrestrial organic matter may promote the formation of organic carbon-rich sediments [e.g., Calvert and Petersen, 1992; Meyers, 1997; Hallam, 1987; Schlanger and Jenkyns, 1976]. Favorable conditions for the formation of argillaceous, organic carbon-rich sedimentary rocks, the so-called black shales, are most known from the mid-Cretaceous where most of our present-day petroleum reserves were generated [e.g., Larson, 1991, and references therein]. Widespread formation of black shales is reported from the Aptian/Albian and Cenomanian/Turonian and is associated with "oceanic anoxic events" (OAEs) [e.g., Arthur et al., 1987; Larson, 1991; Sinninghe Damsté and Köster, 1998; Schlanger et al., 1987; Bralower and Thierstein,

Copyright 2003 by the American Geophysical Union. 0883-8305/03/2002PA000867\$12.00
1987]. Two principal models have been under controversial discussion during the past three decades: (1) oceanwide episodes of "stagnation" in restricted stratified basin similar to the Black Sea, and (2) an increased primary production which causes oxygen minimum zones that impinge on the seafloor and thereby limit the remineralization of organic matter on the seafloor [e.g., Pedersen and Calvert, 1990; Caplan and Bustin, 1998; Saelen et al., 2000; Nijenhuis et al., 1999; Röhl et al., 2001]. An increased supply of terrigenous organic matter may also be an important mechanism for the accumulation of organic carbon in marine sediments [e.g., Stein et al., 1986]. However, many of the these studies are derived from the "middle" Cretaceous low-latitudinal North Atlantic where black shale formation is associated with a relatively high sea level. Because the oil and gas reservoirs of the North Sea were generated in the late Jurassic much attention has more recently been focussed on the JurassicCretaceous boundary. In contrast to the "middle" Cretaceous the Jurassic-Cretaceous boundary was characterized by very low North Atlantic spreading rates, which caused a 


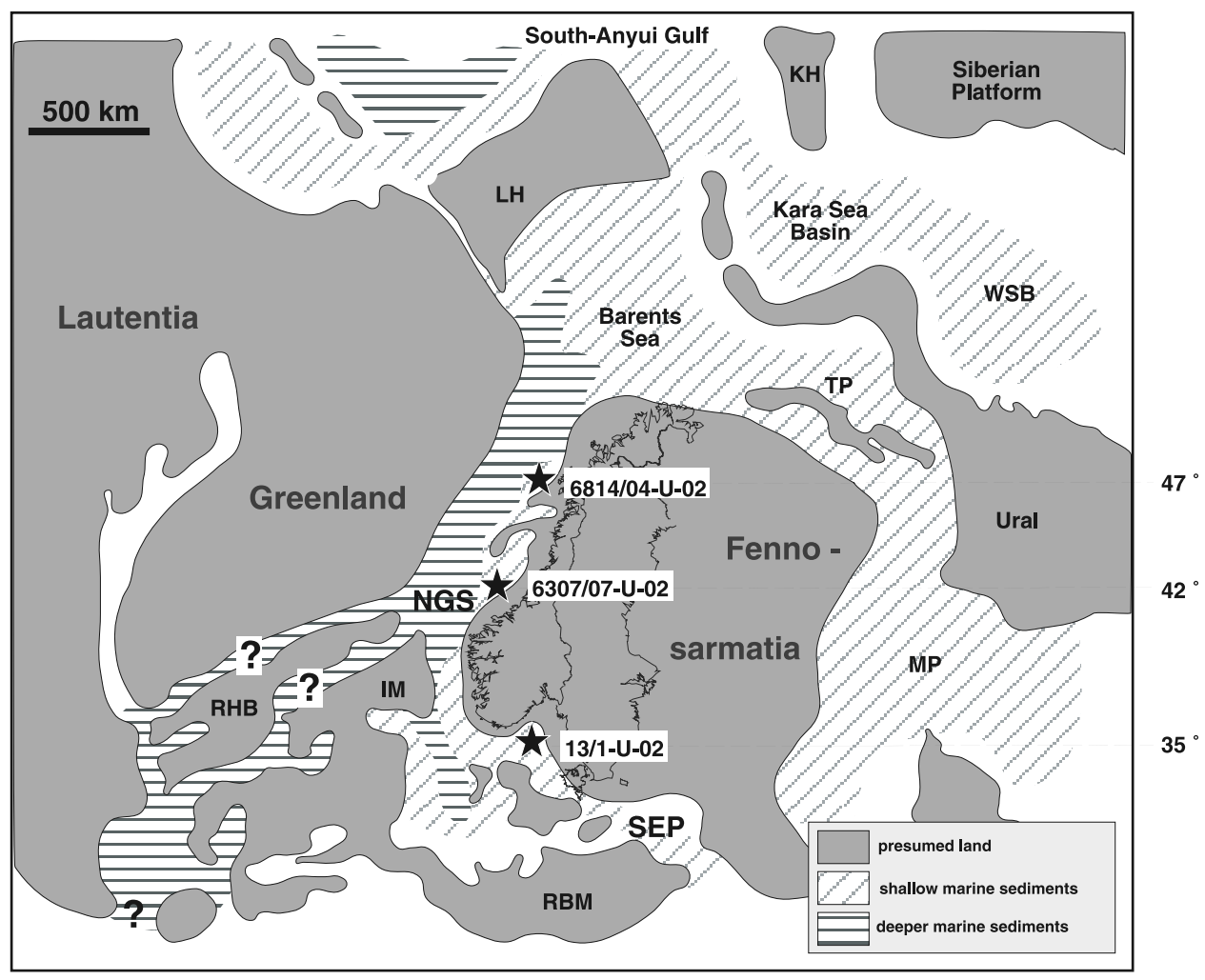

Figure 1. Paleogeographic situation of the Norwegian-Greenland Seaway and surrounding continental masses in the Ryazanian (middle to late Berriasian) (modified after Ziegler [1988]. Core locations are shown relative to the modern coast line (outlines of Norway) and indicated by the asterisk. Paleolatitudes are taken from Mutterlose et al. [2003]. Abbreviations are as follows: IM, Irish Massif; KH, Kara High; LH, Lomonossov High; MP, Moscow Platform; RBM, Rhenish Bohemian Massif; RHB, Rockall-Hatton Bank; TP, Timan Pechora Area; WSB, West Siberian Basin; NGS, Norwegian-Greenland Seaway; SEP, Southeastern Passage.

second-order sea-level low stand [e.g., Haq et al., 1988] and formed a large number of restricted marine environments [e.g., Ziegler, 1988; Hardenbol et al., 1998]. During this time the only direct connection between the North Atlantic and the proto-Arctic Ocean was a narrow and shallow marine passage between Greenland and Fennoscandia, which was more than $1500 \mathrm{~km}$ long and only 200 to $300 \mathrm{~km}$ wide, the Norwegian-Greenland Seaway [e.g., Ziegler, 1988; Doré, 1991; Hay et al., 1999; Mutterlose et al., 2003; Brekke et al., 1999] (Figure 1). The paleogeographic and paleoceanographic situation along the margins of this seaway provided excellent conditions for the formation of black shales, which became eventually petroleum source rocks, e.g., the Hekkingen and Spekk formations exposed along the Norwegian shelf and the adjacent Barents Sea [e.g., Arhus et al., 1987; Worsley et al., 1988; Bugge et al., 1989; Arhus, 1991; Leith et al., 1992; Smelror et al., 1998, 2001a; Bugge et al., 2002; Mutterlose et al., 2003]. The high petroleum generative potential of these late Jurassic to early Cretaceous sequences is also supported by our data (Table 1) [see Peters, 1986]. Therefore the Norwegian-Greenland Seaway (NGS) provides rare opportunity to investigate the formation of black shales during times of sea-level low stand and really high northern paleolatitudes.

\section{Material and Analytical Approach}

[3] We investigated 257 samples from 3 sediment cores drilled offshore of southern and middle Norway (Figure 1). The cores were initially collected and described by Sintef Petroleum Research (former IKU) during economic shallow drilling projects in the late 1980s [e.g., Arhus et al., 1987; Rokoengen et al., 1988; Bugge et al., 1989; Hansen et al., 1991; Leith et al., 1992]. The southernmost drilling hole $13 / 1-\mathrm{U}-02$ is located $57^{\circ} 48^{\prime} \mathrm{N}$ and $08^{\circ} 12^{\prime} \mathrm{E}$ in the western Skagerrak. Hole $6307 / 07-\mathrm{U}-02$ is located $63^{\circ} 27^{\prime} \mathrm{N}$ and $07^{\circ} 14^{\prime} \mathrm{E}$ in the southern part of the Hitra Basin (off Smøla Island), and hole $6814 / 04-\mathrm{U}-02$ is located $68^{\circ} 39^{\prime} \mathrm{N}$ and $14^{\circ} 09^{\prime} \mathrm{E}$ in the northern part of the Ribban Basin (off the Lofoten Islands). We sampled the entire cores with a spacing between 100 and $200 \mathrm{~cm}$ representing time intervals of about 100 to $500 \mathrm{ka}$.

[4] Total carbon (TC), total nitrogen (TN) and total sulfur (TS) contents were analyzed on homogenized samples using LECO elemental analyzers. The organic carbon content 
Table 1. Average Values of Bulk Parameters From Organic and Inorganic Geochemical Analysis and Rock-Eval Pyrolysis for Major Time Intervals $^{\mathrm{a}}$

\begin{tabular}{|c|c|c|c|c|c|c|c|c|c|c|c|c|c|c|c|c|c|}
\hline Core & $\begin{array}{c}\text { Depth, } \\
\text { mbsf }\end{array}$ & Interval & $\begin{array}{c}\mathrm{TC}, \\
\text { wt } \%\end{array}$ & $\begin{array}{c}\mathrm{TN}, \\
\text { wt } \%\end{array}$ & $\begin{array}{c}\text { TS, } \\
\text { wt } \%\end{array}$ & $\begin{array}{c}\mathrm{CaCO}_{3}, \\
\text { wt } \%\end{array}$ & $\begin{array}{r}\mathrm{Fe}_{2} \mathrm{O}_{3}, \\
\text { wt } \%\end{array}$ & $\begin{array}{l}\text { TOC, } \\
\text { wt } \%\end{array}$ & $\mathrm{HI}^{\mathrm{b}}$ & $\mathrm{OI}^{\mathrm{c}}$ & $\begin{array}{c}\mathrm{T}_{\text {MAX }}, \\
{ }^{\circ} \mathrm{C}\end{array}$ & $\mathrm{S} 1^{\mathrm{d}}$ & $S 2^{\mathrm{d}}$ & $\mathrm{S} 3^{\mathrm{d}}$ & $\mathrm{S} 2 / \mathrm{S} 3$ & PI & $\begin{array}{c}\text { Source Rock } \\
\text { Potential }\end{array}$ \\
\hline \multicolumn{18}{|c|}{ 6814/04-U-02 } \\
\hline & $7-39$ & Barremian & 3.40 & 0.15 & 1.0 & 8.0 & 9.0 & 2.40 & 58 & 48 & 436 & 0.1 & 1.5 & 1.2 & 2.1 & 0.07 & poor/fair \\
\hline & $39-44$ & late Hauterivian & 1.70 & 0.04 & 3.6 & 13.9 & 6.0 & 0.10 & 77 & 292 & 494 & 0.0 & 0.1 & 0.2 & 0.1 & 0.08 & none \\
\hline & $44-70$ & Valanginian & 1.90 & 0.06 & 2.9 & 10.8 & 6.6 & 0.60 & 112 & 98 & 460 & 0.1 & 0.6 & 0.4 & 1.9 & 0.11 & none \\
\hline & $70-89$ & Ryazanian & 2.10 & 0.12 & 2.3 & 4.1 & 5.0 & 1.60 & 100 & 90 & 423 & 0.1 & 1.9 & 1.2 & 1.7 & 0.05 & fair \\
\hline & $89-136$ & late Volgian & 4.30 & 0.19 & 3.9 & 11.6 & 7.6 & 2.90 & 187 & 35 & 430 & 0.3 & 5.9 & 0.9 & 8.7 & 0.04 & fair/good \\
\hline & $136-167$ & middle Volgian & 4.80 & 0.22 & 3.9 & 10.8 & 7.5 & 3.50 & 219 & 25 & 429 & 0.4 & 7.6 & 0.9 & 19.0 & 0.04 & good/very good \\
\hline & $167-191$ & early Volgian & 3.70 & 0.20 & 3.5 & 8.4 & 5.4 & 2.70 & 247 & 22 & 425 & 0.3 & 6.5 & 0.6 & 16.4 & 0.05 & good/very good \\
\hline \multicolumn{18}{|c|}{$6307 / 07-U-02$} \\
\hline & $13-34$ & Valanginian & 3.20 & 0.04 & 1.8 & 15.7 & 7.8 & 0.40 & 56 & 152 & 410 & 0.2 & 0.8 & 0.9 & 0.7 & 0.17 & poor \\
\hline & $34-50$ & Ryazanian & 4.70 & 0.15 & 4.3 & 2.8 & 6.4 & 2.70 & 275 & 66 & 413 & 0.3 & 8.8 & 1.5 & 4.9 & 0.05 & good \\
\hline & $50-62$ & late Volgian & 6.30 & 0.21 & 3.3 & 0.8 & 4.0 & 4.30 & 348 & 49 & 409 & 0.7 & 14.6 & 2.0 & 7.3 & 0.05 & very good \\
\hline & $62-74$ & middle Volgian & 6.30 & 0.19 & 4.5 & 1.9 & 5.4 & 3.90 & 371 & 62 & 406 & 0.6 & 14.2 & 2.4 & 6.1 & 0.04 & very good \\
\hline & $74-105$ & early Volgian & 6.80 & 0.18 & 5.4 & 2.8 & 6.1 & 4.20 & 373 & 99 & 407 & 0.8 & 16.0 & 1.9 & 8.5 & 0.05 & very good \\
\hline & $118-145$ & late Volgian & 1.40 & 0.05 & 1.0 & 4.5 & 5.4 & 0.80 & 44 & 79 & 421 & 0.1 & 0.4 & 0.6 & 1.5 & 0.20 & poor \\
\hline & $145-152$ & middle Volgian & 0.80 & 0.04 & 0.5 & 3.6 & 8.7 & 0.30 & 6 & $\mathrm{x}$ & 367 & 0.0 & 0.0 & 0.0 & 0.0 & 0.56 & poor \\
\hline & $152-208$ & early Volgian & 1.80 & 0.05 & 1.0 & 9.4 & 6.5 & 0.70 & 10 & 68 & 381 & 0.1 & 0.1 & 0.4 & 0.2 & 0.56 & poor \\
\hline
\end{tabular}

${ }^{a}$ Estimates of source rock potential according to Espitalié et al. [1977] and Peters [1986].

${ }^{\mathrm{b}}$ Unit of measure, $\mathrm{mg} \mathrm{HC} / \mathrm{g}$ TOC.

${ }^{\mathrm{c}}$ Unit of measure, $\mathrm{mg} \mathrm{CO} 2 / \mathrm{g}$.

${ }^{\mathrm{d}}$ Unit of measure, mg HC/g rock.

(TOC) was determined after carbonate was removed from the samples by hydrochloric acid. The carbonate content was determined by inorganic $\mathrm{CaO}$ measurements with a $\mathrm{CM}$ 5012- $\mathrm{CO}_{2}$ coulometer [e.g., Huffmann, 1977; Engleman et al., 1985] and expressed as $\mathrm{CaCO}_{3}$. To evaluate the reproducibility of carbon and organic carbon data, duplicates were measured routinely. $\mathrm{Fe}_{2} \mathrm{O}_{3}, \mathrm{Al}_{2} \mathrm{O}_{3}$ and $\mathrm{Zr}$ were measured by XRF analysis using a Philips PW 2400 analyzer. The amount of reactive iron was calculated using the empirical formula $\mathrm{Fe}_{\text {reactive }}=\mathrm{Fe}-0.25 * \mathrm{Al}$ (wt \%). TOC-Fe-S relationships were used to estimate the depositional conditions [e.g., Brumsack, 1988; Dean and Arthur, 1989; Lückge et al., 1996; Hofmann et al., 2000], whereas $\mathrm{Zr} / \mathrm{Al}$ ratios describe changes of the relative distance to the paleoshore because high $\mathrm{Zr} / \mathrm{Al}$ ratios usually indicate an increased aeolian input and the proximity to the land [e.g., Hinrichs et al., 2001]. In normal marine sediments the $\mathrm{C} / \mathrm{N}$ ratio may improve the differentiation between terrestrial and marine organic matter, where a high ratio indicates a more terrestrial signal [e.g., Meyers, 1997, and references therein]. However, in many fossil sediments, especially under anoxic conditions, $\mathrm{C} / \mathrm{N}$ ratios are often reported to show remarkable exceptions from this "rule" [e.g., Rau et al., 1987; Lüniger and Schwark, 2002; Twichell et al., 2002]. Moreover, Langrock et al. [2003] demonstrate that in late Jurassic algae-rich sapropels from the Barents Sea high $\mathrm{C} / \mathrm{N}$ ratios may indicate a high degree of bottom water anoxia.

[5] Stable carbon isotopes of bulk organic carbon $\left({ }^{13} \mathrm{C}_{\mathrm{org}}\right)$ was measured on de-carbonated samples from core 6307/07U2 and 6814/04-U2. Samples were analyzed by high-temperature combustion in a Heraeus CHN elemental analyzer connected to a Finnigan MAT Delta $\mathrm{S}$ isotope ratio massspectrometer [see Fry et al., 1992]. The isotopic composition is reported as $\delta$-values [in \%o] relative to the international Vienna PDB standard [Coplen, 1995]. The analytical reproducibility based on replicate analyses was better than $\pm 0.2 \%$.
[6] Kerogen typing, determination of source rock generative potential and organic matter (OM) maturity were conducted according to Espitalié et al. [1977] and Peters [1986] using a Rock-Eval II (plus S3 unit). The hydrogen index (HI) was calculated from the amount of pyrolyzable hydrocarbons (S2 value) based on the TOC content, and the oxygen index (OI) was calculated from the amount of associated carbon dioxide ( $\mathrm{S} 3$ value) on the basis of the TOC content. Indices were used in a HI/OI diagram to estimate kerogen types (I-IV), their potential sources and thermal maturity [c.f. Espitalié et al, 1977; Peters, 1986]. The alternative presentation of S2 values against TOC contents is an additional kerogen type determination to avoid mineral matrix effects and to estimate the amount of "dead" (inert) organic carbon [e.g., Langford and Blanc-Valleron, 1990; Horsfield et al., 1994; Cornford et al., 1998; Lüniger and Schwark, 2002]. However, the kerogen type classification is only a rough estimate that depends on composition, preservation and thermal maturity of the organic matter. Hence interpretation is difficult without invoking other parameters such as maceral data obtained by petrographic studies.

[7] Consequently, reflected light microscopy was performed on polished blocks of rock and kerogen isolates using a Zeiss Axiophot equipped with normal white and ultraviolet light. The organic matter composition was determined by point-counting maceral analysis following largely the ICCP nomenclature described in the work of Taylor et al. [1998]. In this paper we summarized the observed macerals into vitrinite, inertinite, terrigenous liptinite and marine-aquatic liptinite. Particles less than $5 \mu \mathrm{m}$ in size and small nonspecific fragments were given the suffix detrinite, e.g., liptodetrinite. Microscopic imaging was performed with a Zeiss Axiocam digital video camera.

[8] To estimate the level of oxygenation in the water column we performed a pyrite size distribution analysis using incident white light [c.f. Wilkin et al., 1996, 1997]. 


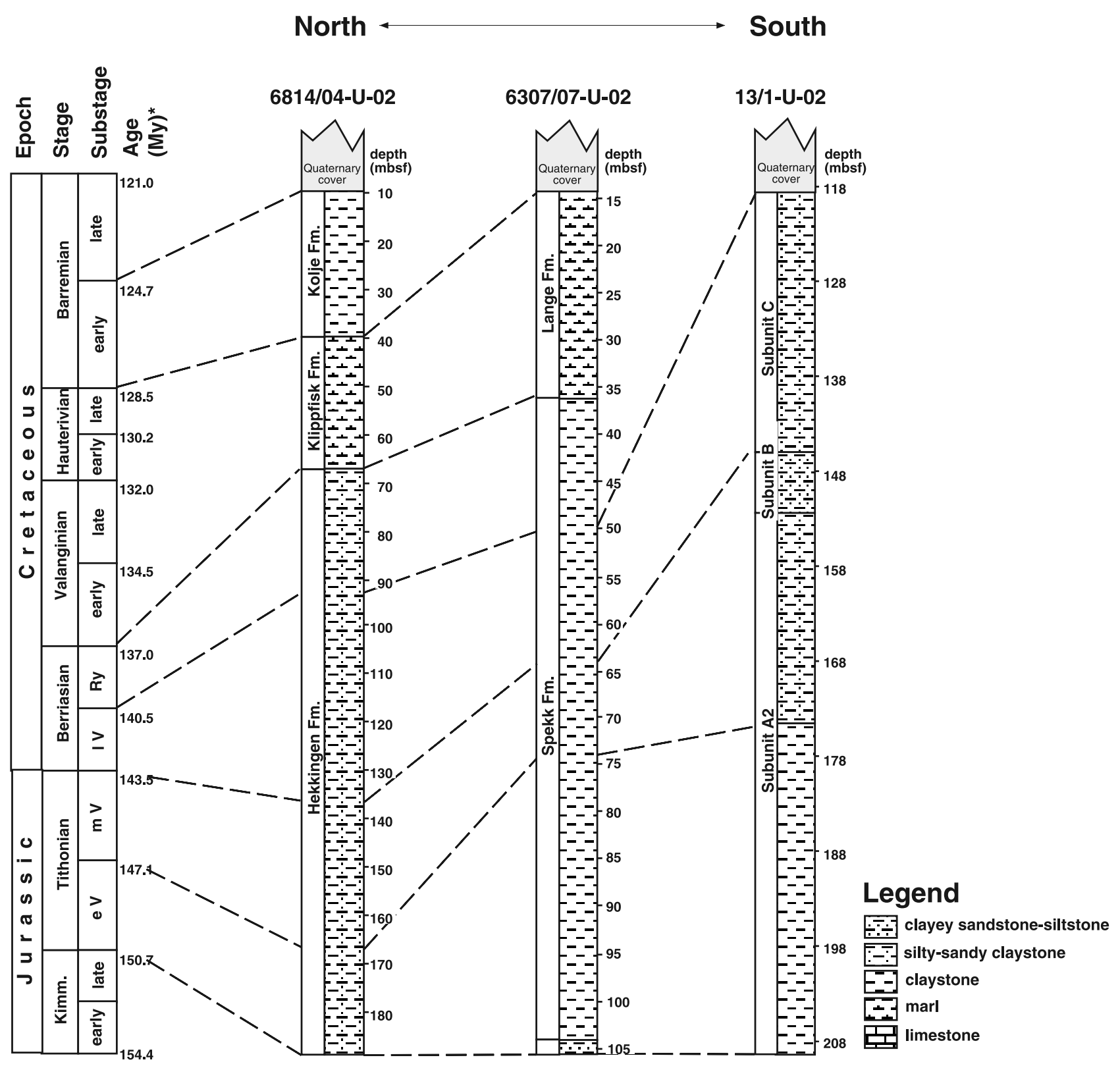

* data from Mutterlose et al. (in press)

Figure 2. Lithostratigraphic correlation between the investigated cores [after Arhus et al., 1987; Rokoengen et al., 1988; Mutterlose et al., 2003] using the ages of Hardenbol et al. [1998]. The lithological units are also displayed by their regional terminology, usually given fish names, e.g., the Hekkingen Formation. Note the differences in sedimentation rate from south to north. Abbreviations are as follows: Kimm., Kimmeridgian; eV, early; mV, middle Volgian; IV, late Volgian; Ry, Ryazanian.

We determined the amount and diameters of total pyrite, pyrite framboids, and idiomorphic crystals on 10 representative samples counting at least 100 grains each.

\section{Lithology and Stratigraphy}

[9] The Late Jurassic to Early Cretaceous sedimentary successions of the Norwegian-Greenland Seaway (NGS) were described by several authors [e.g., Arhus et al., 1987; Rokoengen et al., 1988; Worsley et al., 1988; Bugge et al.,
1989; Lippard and Rokoengen, 1989; Arhus, 1991; Leith et al., 1992; Smelror et al., 2001a, 2001b; Mutterlose et al., 2003]. The sediments deposited during the Volgian and Ryazanian are characterized by dark, dominantly laminated and relatively organic carbon-rich clay stones and silty clay stones. Some of these black shales are also considered as oil shales, e.g., the Spekk Formation and the Hekkingen Formation (Figure 2), because they yield liquid hydrocarbons when artificially matured. However, during the Ryazanian and early Valanginian these facies were gradu- 


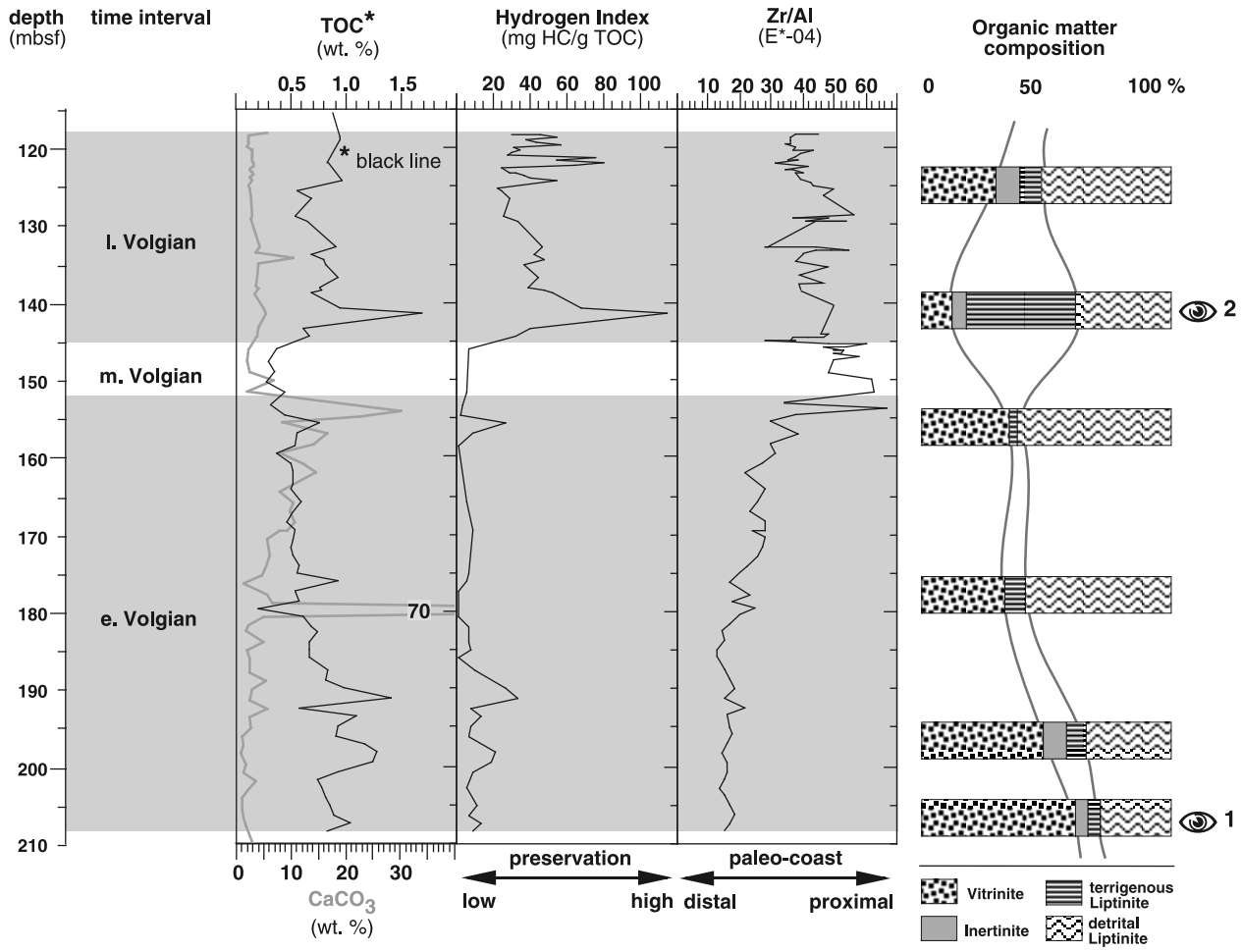

Figure 3. Diagram showing TOC, $\mathrm{CaCO}_{3}, \mathrm{HI}, \mathrm{Zr} / \mathrm{Al}$ ratio, and organic matter composition of core 13/1U-02 plotted against depth. Terms of organic matter preservation are displayed along with the HI value, and interpretations of the relative position to the paleocoast are displayed with the $\mathrm{Zr} / \mathrm{Al}$ ratio. The collective quantity of inertinite plus terrestrial liptinite is enveloped by solid lines, because they may be derived by wind. (Eyes refer to digital picture of OM composition, numbers refer to plates in Appendix A.)

ally succeeded by more and more light-colored, silty and/or calcareous sediments typically associated with a decrease in organic carbon. This calcareous facies is called the Klippfisk Formation, which dominated the northern part of the NGS and the western Barents Sea [e.g., Smelror et al., 1998; Bugge et al., 2002], whereas the time-equivalent Lange Formation dominates the middle NGS. The late Hauterivian (not always documented in the sedimentary record) is usually barren of organic carbon, and signals the end of an approximately $10 \mathrm{Ma}$ episode of black shale formation. These calcareous open-marine sequences are locally succeeded (usually after a hiatus) by dark clay stones or silty clay stones of the Barremian Kolje Formation, containing moderate organic carbon contents (Figure 2). The investigated cores from the NGS reflect these regional sedimentary patterns, whereas the core from the Skagerrak was selected to represent the Southeastern Passage (SEP) to the Tethys realm.

[10] The problem of stratigraphic control on marine sediments containing thick laminated black shale sequences is the relative scarcity of fossils within these sequences. Low clastic sedimentation inhibits fast burial and preservation, and allows scavenging. Therefore a combined investigation on palynomorphs, macrofossils, and foraminifers was performed to gain stratigraphic control [e.g., Hansen et al., 1991; Smelror et al., 1998, 2001b; Mutterlose et al., 2003]. The latter produced a reasonable stratigraphic framework by comparing peaks from spectral analysis (assumed as astro- nomical sedimentation rates) with linear sedimentation rates obtained from the investigations mentioned above (see Figure 2).

\section{Results}

\subsection{Bulk Geochemical Parameters}

[11] For all three cores, average values of bulk elemental composition and Rock-Eval data according to time intervals are summarized in Table 1.

[12] Total organic carbon (TOC) contents of core 13/1-U02 range from 0.1 to 1.7 wt $\%$, but most values remain below $1 \mathrm{wt} \%$. There is a continuous decrease in TOC from the base early Volgian to the middle Volgian, until a single maximum of $1.7 \mathrm{wt} \%$ introduces the base late Volgian (Figure 3). Hydrogen Index (HI) values are very low, ranging between 10 and 40 (mg HC/g TOC) in the early and middle Volgian, and somewhat higher values of about 20 to 100 (mg HC/g TOC) in the late Volgian. Values for $\mathrm{Fe}_{2} \mathrm{O}_{3}$ are relatively high and range from 3 to $10 \mathrm{wt} \%$, whereas sulfur values are relatively low and range from 1 to 3 wt \%. The $\mathrm{Zr} / \mathrm{Al}$ ratio is about 15 in the lower early Volgian and continuously increases to about 65 in the middle Volgian.

[13] Core $6307 / 07-U-02$ is characterized by TOC contents between 0.1 and $7.0 \mathrm{wt} \%$ that continuously decrease from the early Volgian to the late Ryazanian. The decrease is particularly rapid through the Ryazanian (Figure 4). Except 


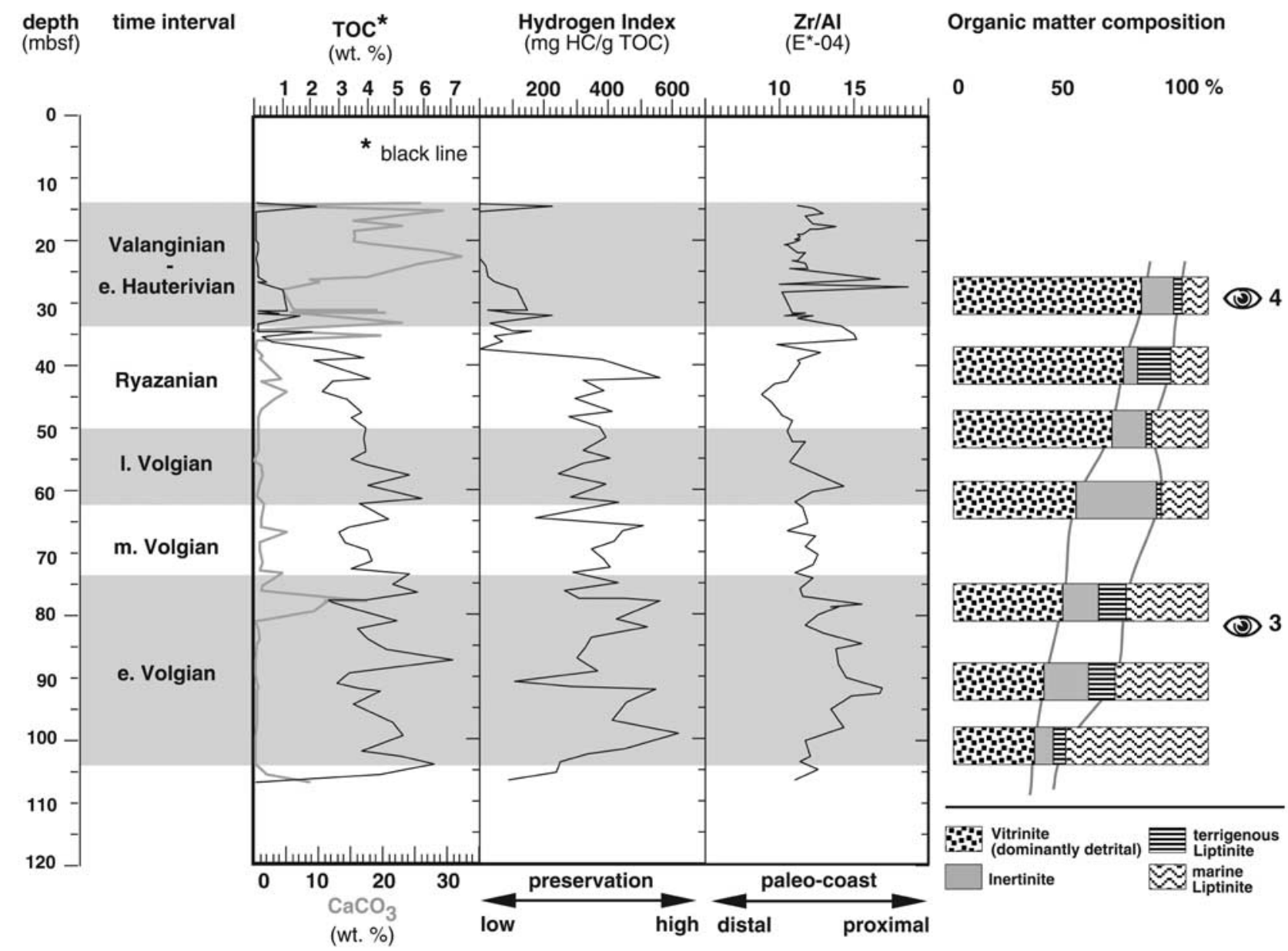

Figure 4. Diagram showing $\mathrm{TOC}, \mathrm{CaCO}_{3}, \mathrm{HI}, \mathrm{Zr} / \mathrm{Al}$ ratio, and organic matter composition of core 6307/07-U-02 plotted against depth. Terms of organic matter preservation are displayed along with the HI value, and interpretations of the relative position to the paleocoast are displayed with the $\mathrm{Zr} / \mathrm{Al}$ ratio. The collective quantity of inertinite plus terrestrial liptinite is enveloped by solid lines, because they may be derived by wind. (Eyes refer to digital picture of OM composition, numbers refer to plates in Appendix A.)

for a few fluctuations in the early Valanginian the uppermost 20 meters of the core are virtually barren of organic carbon. HI values show high variability between 200 to 600 (mg HC/g TOC) from the early Volgian to the late Ryazanian. In the Valanginian values drop below 200 (mg $\mathrm{HC} / \mathrm{g}$ TOC) and reach zero in the Hauterivian. Stable carbon isotope analysis yields $\delta^{13} \mathrm{C}_{\mathrm{ORG}}$ values from $-29 \%$ in the Volgian and $-20 \%$ in the Valanginian. The sediments show high $\mathrm{Fe}_{2} \mathrm{O}_{3}$ and sulfur contents ranging from 3 to $13 \mathrm{wt} \%$, and 0.1 to $13 \mathrm{wt} \%$, respectively. The $\mathrm{Zr} /$ Al ratio is about 15 in the early Volgian and decreases to about 6 in the Ryazanian.

[14] TOC contents of core 6814/04-U-02 range from 0.1 to $4.8 \mathrm{wt} \%$ and decrease similar to those in core $6307 / 07$ U-02 (Figures 4 and 5). Fluctuations in the early Valanginian are also comparable to core 6307/07-U-02, and the succeeding Hauterivian is virtually barren of organic carbon. HI values range from 200 to 400 [mg HC/g TOC] in the early Volgian and from 100 to 200 in the Ryazanian. The Valanginian is marked by values below 100 (mg HC/g
TOC), whereas no values can be calculated in the Hauterivian because the TOC is too low. Stable carbon isotope analysis reveals $\delta^{13} \mathrm{C}_{\mathrm{ORG}}$ values from $-30 \%$ in the Volgian and $-26 \%$ in the Valanginian. $\mathrm{Fe}_{2} \mathrm{O}_{3}$ concentrations range from 2.6 to $21.4 \mathrm{wt} \%$, and sulfur values range from 0.1 to $6.9 \mathrm{wt} \%$. The $\mathrm{Zr} / \mathrm{Al}$ ratio is about $25(2 \times$ higher compared to core $6307 / 07-\mathrm{U}-02$ ), and there seems to be no change from the middle Volgian to the late Ryazanian (Figure 4). The Valanginian and early Hauterivian is marked by strong fluctuations in the $\mathrm{Zr} / \mathrm{Al}$ ratio, where maximum values reach 50 to 60 . The succeeding Barremian reveals a relatively stable ratio of about 15 .

\subsection{Maceral Composition}

[15] In core $13 / 1-\mathrm{U}-02$ vitrinite makes up 10 to $60 \%$ of the particulate organic matter (POM), and includes a moderate portion of detritus (Figure A1). There is a general decrease in the amount of vitrinite from base to top of the core almost parallel to the TOC content, except for the base late Volgian. As the counterpart to vitrinite the amount of 


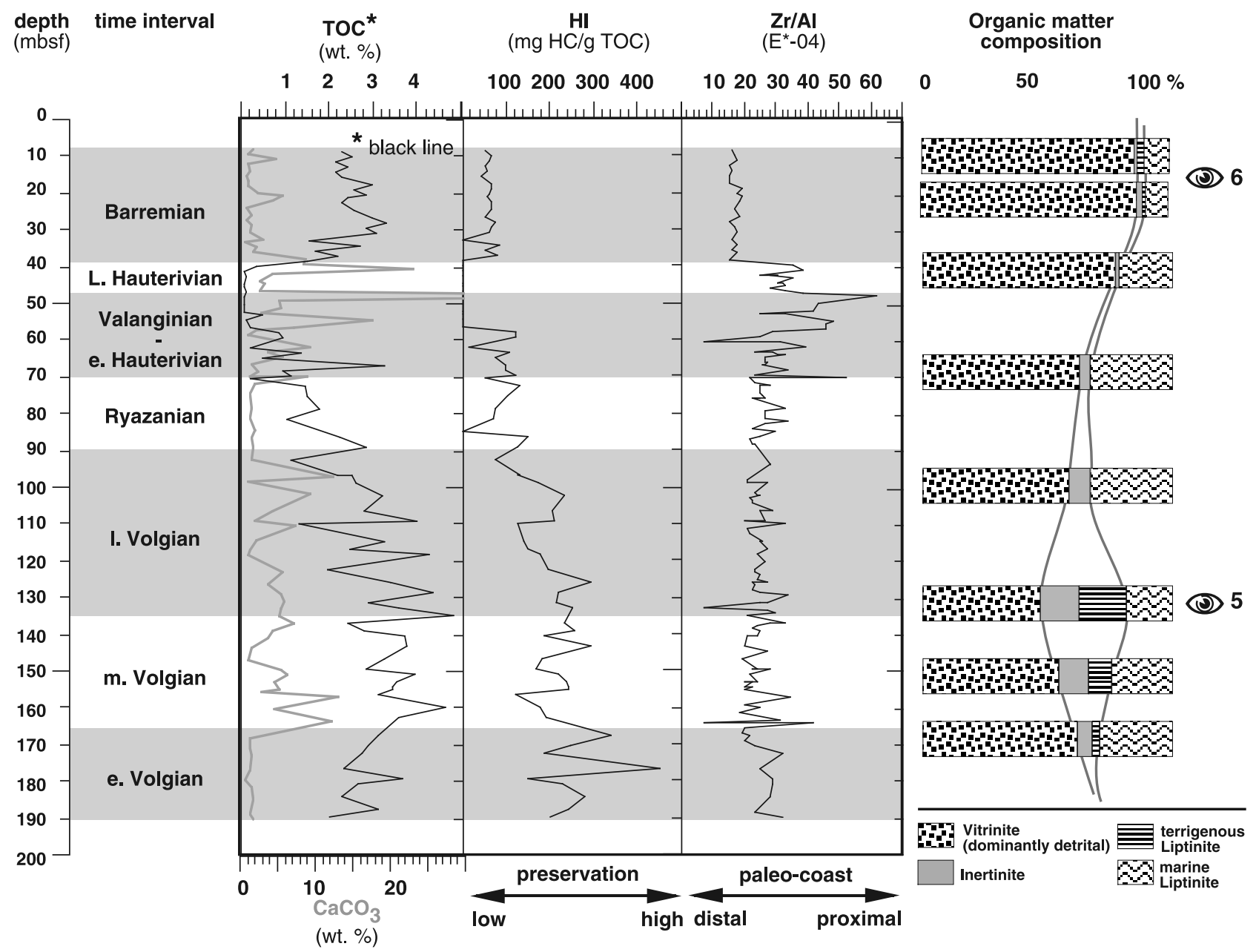

Figure 5. Diagram showing $\mathrm{TOC}, \mathrm{CaCO}_{3}, \mathrm{HI}, \mathrm{Zr} / \mathrm{Al}$ ratio, and organic matter composition of core 6814/04-U-02 plotted against depth. Terms of organic matter preservation are displayed along with the HI value, and interpretations of the relative position to the paleocoast are displayed with the $\mathrm{Zr} / \mathrm{Al}$ ratio. The collective quantity of inertinite plus terrestrial liptinite is enveloped by solid lines, because they may be derived by wind. (Eyes refer to digital picture of OM composition, numbers refer to plates in Appendix A.)

liptodetrinite makes up 25 to $60 \%$ of the POM (Figure 3). Whereas terrigenous liptinite (5 to $40 \%$ ) and inertinite (1 to $10 \%)$ are of minor importance, except for the late Volgian. The base late Volgian is marked by an increased amount of terrigenous liptinite, which makes up to $35 \%$ POM, and produces high peaks in TOC and HI, respectively (Figures 3 and $\mathrm{A} 2$ ).

[16] The POM of core $6307 / 07-\mathrm{U}-02$ is dominated by vitrinite, and includes a relatively high proportion of detritus (Figure 4). The general change in composition through time reveals a clear picture. The amount of vitrinite increases constantly from about $30 \%$ in the early Volgian up to $80 \%$ in the Valanginian, which is counterparallel to the TOC content. The marine liptinite makes up the second major group, including a moderate to high proportion of detritus. It is clearly illustrated that its abundance declines steadily from about $60 \%$ in the early Volgian (see Figures 4 and A3) to about $10 \%$ in the Valanginian (see Figures 4 and A4). The amount of inertinite and terrigenous liptinite is generally much more important compared to core $13 / 1-\mathrm{U}-02$, and ranges from 5 to $20 \%$ and 1 to $15 \%$ of the POM, respectively. In particular, the amount of inertinite shows a symmetrical distribution with lowest values in the early Volgian and in the Valanginian and with a pronounced maximum at the base late Volgian.

[17] The organic matter composition of core 6814/04-U2 is different from the others, because it is heavily dominated by vitrinite, which reaches up to $90 \%$ of the POM (Figure 5). The detrital fraction is also much larger compared to the other cores. Similar to core 6307/07-U-02 the amount of vitrinite is always negatively correlated to the TOC curve. Another difference is that vitrinite first decreases from about $60 \%$ in the late early Volgian to its minimum in the early late Volgian (Figures 5 and A5). It does not increase again before the late Volgian (where the TOC content is highest) to reach about $90 \%$ in the Barremian (Figure A6). Marine liptinite is only a minor component (10 to $30 \%$ ), and has its maximum from the late Volgian to the late Ryazanian. Inertinite and terrigenous liptinite seem to correlate, and both increase mutually from $10 \%$ in the late early Volgian 
to $30 \%$ in the early late Volgian. Shortly thereafter inertinite and terrigenous liptinite decrease to insignificant amounts.

\section{Discussion}

\subsection{Sources and Preservation of Organic Matter}

[18] Determination of the origin and preservation of individual macerals provides information about the distance from their sources and the depositional conditions. To obtain this information we performed organic petrography supported by Rock-Eval data, and we discuss the applicability of $\delta^{13} \mathrm{C}_{\mathrm{ORG}}$ isotope data.

[19] The organic matter of the Southeastern Passage (SEP) appears to be a mixture of marine and terrestrial organic matter, but the material presumably derived from marine sources is highly disintegrated. Hence most of the detrital liptinite (see Figure 3) is of uncertain origin, though we found a few indicators for a marine source, e.g., dinocysts and algae. However, owing to poor preservation these relatively hydrogen-rich precursors now appear as the large amount of type III kerogen, as reflected in the HI/OI and S2/ TOC diagrams (Figures 6 and 7). We found the relatively lipid-rich OM derived from terrestrial sources (spores and

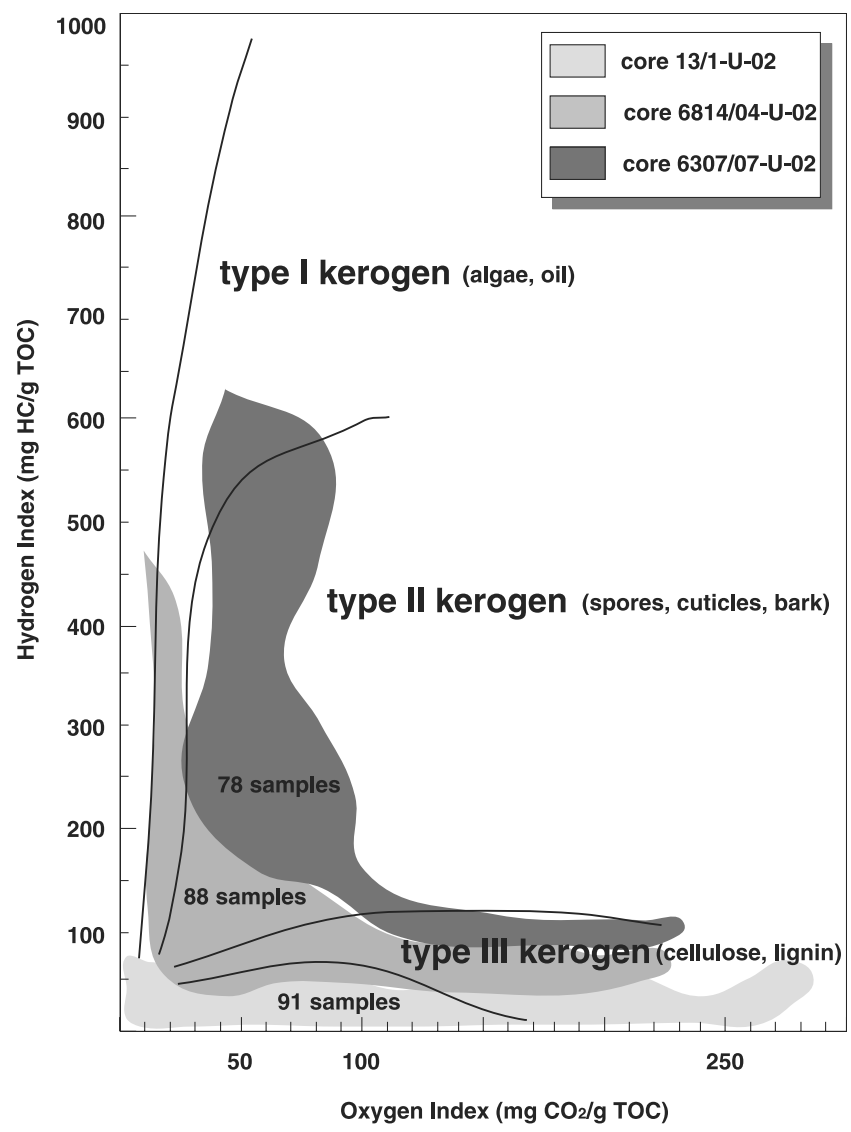

Figure 6. Results of Rock-Eval pyrolysis from all three sediment cores plotted in a HI/OI van Krevelen-type diagram showing different types of OM (type I-IV kerogen) and their potential sources [c.f. Espitalie et al., 1977; Peters, 1986]. Sample clusters were generalized by different fields of gray.
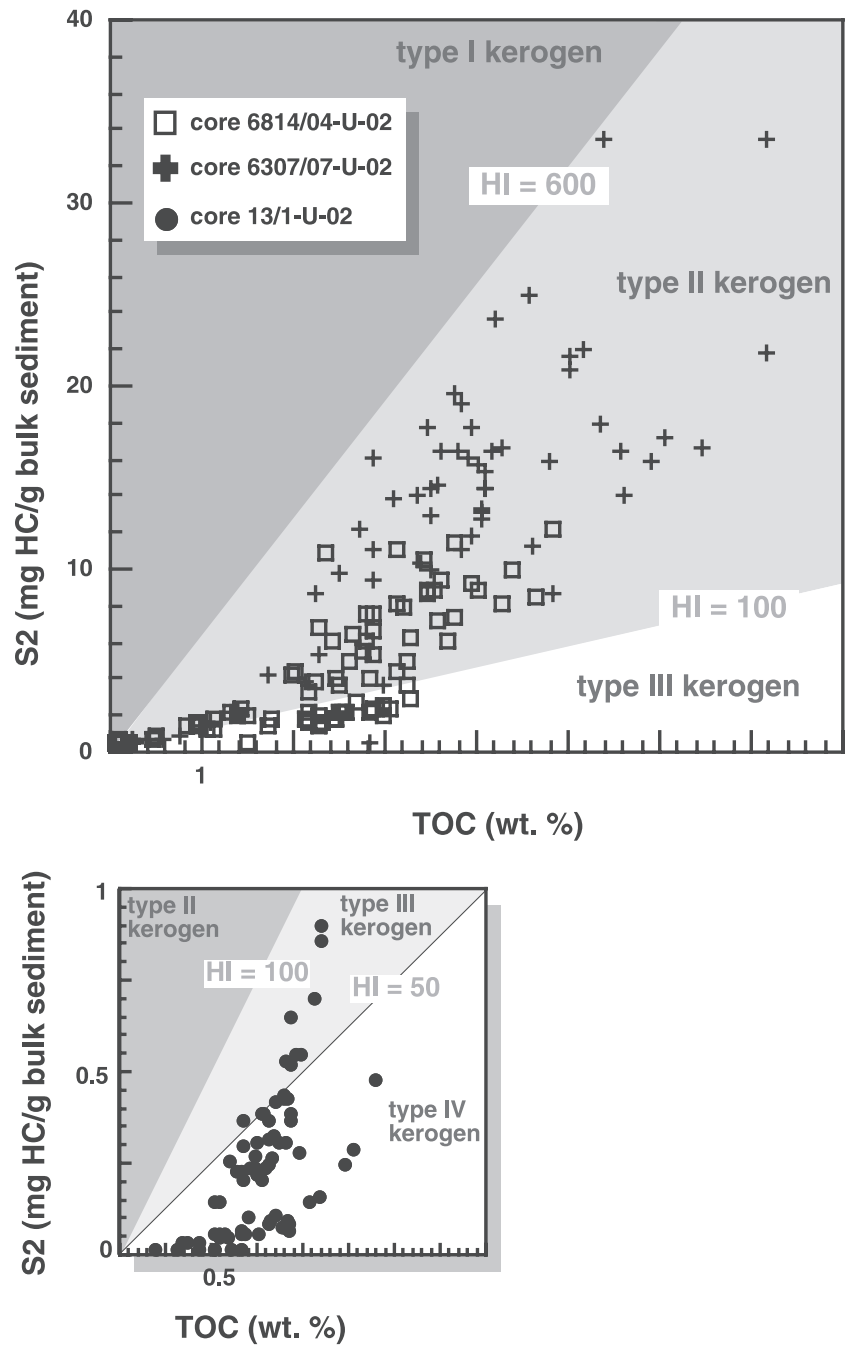

Figure 7. Relationship between S2 and TOC for alternative kerogen type determination. The closer the samples plot along a line with a constant HI value, the more likely is organic carbon accumulation controlled by preservation and mixing of terrestrial and marine OM [e.g., Horsfield et al., 1994; Lüniger and Schwark, 2002; Tribovillard et al., 2001]. Deviations in the S2 or TOC direction suggests elevated primary production, or increased supply of terrigenous OM has influenced the accumulation of organic carbon, respectively. Interception with TOC axis may indicate the absorptive capacity of the mineral matrix [e.g., Langford and Blanc-Valleron, 1990], or the percentage of "dead" organic carbon [Cornford et al., 1998].

pollen) is much better preserved than material from marine sources (Figure A2). The macerals from cellulose and ligninrich land-plants show a broad spectrum of maturation stages, from dark-brown vitrinite to light-gray primary fusinite. These macerals are considered as original type III and IV kerogen presented in the HI/OI and S2/TOC diagrams (Figures 6 and 7). In general, we observe a decrease of land-plant debris (vitrinite, including vitrodetrinite) from the base early Volgian to the early late Volgian (see Figure 3) and a positive correlation with the TOC content. 

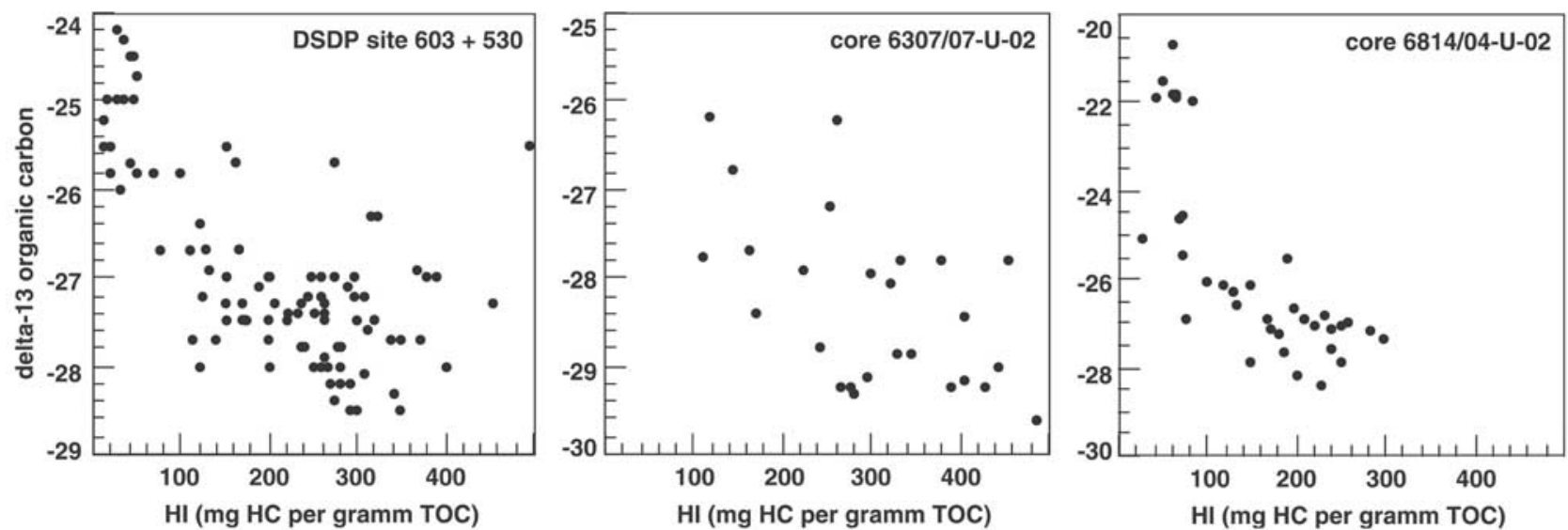

Figure 8. Relationships between $\delta^{13} \mathrm{C}_{\mathrm{ORG}}$ and $\mathrm{HI}$ values of core 6814/04-U-02 and core 6307/07-U-02 (Figure 8) demonstrate that hydrogen-rich organic matter is positively correlated with lighter $\left({ }^{13} \mathrm{C}\right.$ depleted) values, and vice versa. This abnormal (different from modern) relationship is also reported from other Mesozoic sites, e.g., DSDP sites 367, 530 [Dean et al., 1986], and 603 [Arthur et al., 1985] which are summarized in Figure 8. This relationship seems to be stronger developed with increasing anoxia, and/or higher northern latitudes [Langrock et al., 2003].

[20] The Norwegian-Greenland Seaway (NGS) shows a very different picture. The organic matter is clearly derived from both marine/aquatic and terrestrial sources and the preservation is much better [e.g., Langrock and Stein, 2001]. We observe a general increase of land-plant debris (vitrinite, including vitrodetrinite) from the early Volgian to the early Barremian, although this course starts somewhat later in the northern NGS location (Figure 5). However, most prominent is the high abundance of well-preserved liptinite fragments $(\geq 10 \mu \mathrm{m})$ and liptodetrinite $(\leq 5-10 \mu \mathrm{m})$, which reveal their marine sources (e.g., algae, dinocysts). We found many physically intact algae at various depths (Pediastrum, Botryococcus, Tasmanites, and most important dinoflagellate cysts) that may be derived from estuarine, lagoonal and/or pelagic sources. Their relatively high preservation results in type II kerogen (Figures 6 and 7). Terrigenous liptinites are dominated by a variety of fairly to very well-preserved spores and pollen (Figures A3 and A5), producing type II and II/III kerogen. Therefore compared to the SEP a much wider spectrum of kerogen types appears in the HI/OI and S2/TOC diagrams (Figures 6 and 7). However, the most striking difference to the SEP is the negative relationship between TOC content and the amount of vitrinite.

[21] Determination of OM sources can be supported by the application of $\delta^{13} \mathrm{C}_{\mathrm{ORG}}$ data [e.g., France-Lanord and Derry, 1994; Meyers, 1997; Schouten et al., 1997; Routh et al., 1999; Onstad et al., 2000; Van de Schootbrugge et al., 2000], but the isotopic signature of late Mesozoic sediments appears to be substantially different from modern sediments. As long as oceanic $\mathrm{CO}_{2}$ is enriched in ${ }^{13} \mathrm{C}$, sediments dominated by marine $\mathrm{OM}$ should produce higher, i.e., isotopically heavier, $\delta^{13} \mathrm{C}_{\mathrm{ORG}}$ values than sediments dominated by land-plant derived material. In contrast, we observed that our sediments rich in marine $\mathrm{OM}$ are characterized by $\delta^{13} \mathrm{C}_{\mathrm{ORG}}$ values from -25 to $-30 \%$, whereas the sequences rich in terrestrial $\mathrm{OM}$ show values from -20 to
$-25 \%$. A similar inverted relationship is reported from various DSDP sites in the lower Cretaceous North Atlantic [e.g., Arthur et al., 1985; Dean et al., 1986] (Figure 8). Several potential mechanisms were discussed to explain these unusual isotopic signatures in late Mesozoic sediments, such as diagenesis, increased atmospheric $\mathrm{CO}_{2}$ partial pressure, and more exhaustive photosynthetic ${ }^{13} \mathrm{C}$ fractionation of marine phytoplankton [see Arthur et al., 1985; Dean et al., 1986; Meyers, 1997; Ehrbacher et al., 1999 and references therein]. Rau et al. [1987] demonstrated a good correlation between low $\delta^{15} \mathrm{~N}$ and low $\delta^{13} \mathrm{C}$ values in Cretaceous black shales, where the ${ }^{15} \mathrm{~N}$ depletion is suggested as a result of periodically extensive denitrification by $\mathrm{N}_{2}$-fixing bacteria set in largely anoxic or suboxic environments with slow deep-water turnover. This coincides with our interpretation of black shale formation of the Hekkingen Fm and Spekk Fm (see below).

\subsection{Depositional Environments}

[22] There are several processes that increase the amount of organic carbon that is preserved in the sedimentary record, e.g., anoxic bottom waters (= lack of bioturbation), reduced input of clastic material (= lack of dilution), high primary production (= benthic overload), high bulk accumulation rates (= rapid burial), and high supply of terrestrial organic matter [e.g., Müller and Suess, 1979; Demaison and Moore, 1980; Stein et al., 1986; Arthur et al., 1987; De Graciansky et al., 1987; Meyers, 1997]. To assess the depositional conditions we interpreted the pyrite size distribution [e.g., Wilkin et al., 1996, 1997], TOC-Fe-S relationships [e.g., Brumsack, 1988; Dean and Arthur, 1989; Lückge et al., 1996; Hofmann et al., 2000], and sedimentation rate/organic carbon relations [e.g., Stein, 1990].

[23] We found autochthonous pyrite framboids in all studied cores and almost all depths, except for the Valanginian and Hauterivian of core 6307/07-U-02. Autochthonous pyrite formation indicates anoxic conditions, but pyrite 
Table 2. Pyrite Size Distribution Inferred From Reflected Light Microscopy [e.g., Wilkin et al., 1996, 1997] ${ }^{\mathrm{a}}$

\begin{tabular}{|c|c|c|c|c|c|}
\hline Location & Time Interval & $\begin{array}{c}\text { Pyrite as } \\
\text { Framboids, \% }\end{array}$ & $\begin{array}{c}\text { Mean } \\
\text { Diameter, } \mu \mathrm{m}\end{array}$ & $\begin{array}{c}\text { Size } \\
\text { Variability }\end{array}$ & Interpretation \\
\hline \multirow{2}{*}{ 13-1-U-01 } & late Volgian & 88 & 13.0 & high & oxic-dysoxic \\
\hline & early Volgian & 86 & 12.0 & high & oxic - dysoxic \\
\hline \multirow[t]{2}{*}{ 6307-07-U-02 } & Valanginian - Hauterivian & no pyrite & no pyrite & no pyrite & oxic \\
\hline & Volgian - Ryazanian & 98 & 6.0 & low & anoxic \\
\hline \multirow[t]{3}{*}{ 6814-04-U-02 } & Barremian & 74 & 7.0 & low & oxic - dysoxic \\
\hline & Valanginian - Hauterivian & 7 & 8.0 & low & oxic \\
\hline & Volgian - Ryazanian & 98 & 7.0 & medium & anoxic-suboxic \\
\hline Framvaren & Quaternary & $80-85$ & 5.8 & & oxic-dysoxic \\
\hline Wallops Island & Quaternary & $70-75$ & 7.6 & & oxic - dysoxic \\
\hline Black Sea & Quaternary & 95 & 5.1 & low & anoxic \\
\hline
\end{tabular}

${ }^{a}$ A high percentage, a low average diameter, and/or a low size variability of pyrite framboids suggest a formation under more anoxic conditions, predominantly within the water column. Modern surface sediments, e.g., from the Black Sea, can be related to the Volgian black shale sequences of core 6307/07-U-02 and 6814/04-U-02. Positive relationships to modern analogues are indicated by asterisks.

framboids that have formed within an anoxic water column, e.g., in the modern Black Sea, are typically smaller and less variable in size than those formed in the pore spaces of sediments underlying oxic and dysoxic water columns [e.g., Wilkin et al., 1996, 1997]. Our investigations clearly revealed that sediments with a high TOC content are dominated by pyrite framboids that are particularly small and less variable in size. The Volgian and Ryazanian sediments of the NGS basins show that about $98 \%$ of the total pyrite occurs as framboids (Table 2). Average diameters range from $6 \mu \mathrm{m}$ to $7 \mu \mathrm{m}$ with a low variability in size. This relatively uniform size is obtained when pyrite is formed within the water column and sinks to the bottom by means of gravity, which suggests that at least a distinct layer of the water column was anoxic [e.g., Wilkin et al., 1996, 1997]. The sediments of the succeeding Valanginian and Hauterivian of core $6814 / 04-\mathrm{U}-02$ reveal that only $7 \%$ of the pyrite occurs as relatively uniform framboids, and $93 \%$ is nonframboidal that has likely been formed below the sediment surface. During the identical time period no pyrite was formed in core 6307/07-U-02, indicating the absence of $\mathrm{H}_{2} \mathrm{~S}$ owing to the lack of OM. In core 13/1-U-02 less than $88 \%$ of the pyrite are framboids, and much of the framboids have formed huge aggregates filling the pore spaces in the sediment. The diameters of the framboids also differ from those in the other cores and show an average of $12 \mu \mathrm{m}$, ranging from 4 to $100 \mu \mathrm{m}$. This suggests a rather oxygenated water column, and that pyrite has formed predominantly in the sediment.

[24] The TOC-Fe-S ternary diagrams (Figures 9a-9c) display the limiting factors for pyrite formation to evaluate the depositional conditions [e.g., Berner and Raiswell, 1983; Berner, 1984; Brumsack, 1988; Dean and Arthur, 1989; Hofmann et al., 2000]. In the Skagerrak location most samples plot within a relatively narrow field, reflecting a low variability between the parameters (Figure 9a). Pyrite formation was chiefly limited by the lack of labile hydrogen-rich organic matter, because sulfate is unlimited in marine environments. Hence the sediments were likely deposited under relatively stable oxic conditions throughout

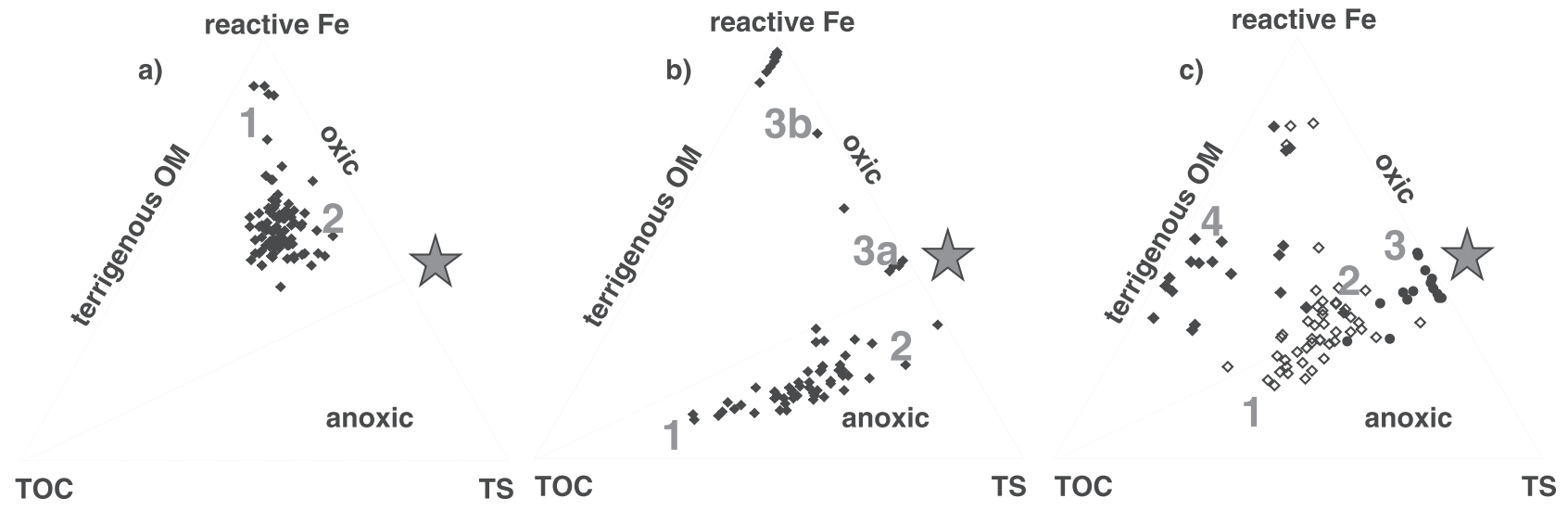

Figure 9. TOC-Fe-S ternary diagram showing the limiting factors for pyrite formation [e.g., Brumsack, 1988; Dean and Arthur, 1989; Hofmann et al., 2000] for (a) core 13/1-U-02, (b) core 6307/07-U-02, and core (c) 6814/04-U-02. Formation of pyrite $\left(\mathrm{FeS}_{2}\right)$ is provided along the solid line. Below this line pyrite formation is limited by reactive iron, probably reflecting anoxic conditions. Above the line pyrite formation is limited by the absence or composition of OM, e.g., samples plot to the left if easy-tometabolize compounds are absent. An evolutionary trend of changing depositional conditions is demonstrated by different numbers representing (1) the early Volgian, (2) the late Volgian, (3) the Valanginian and Hauterivian, and (4) the Barremian. 


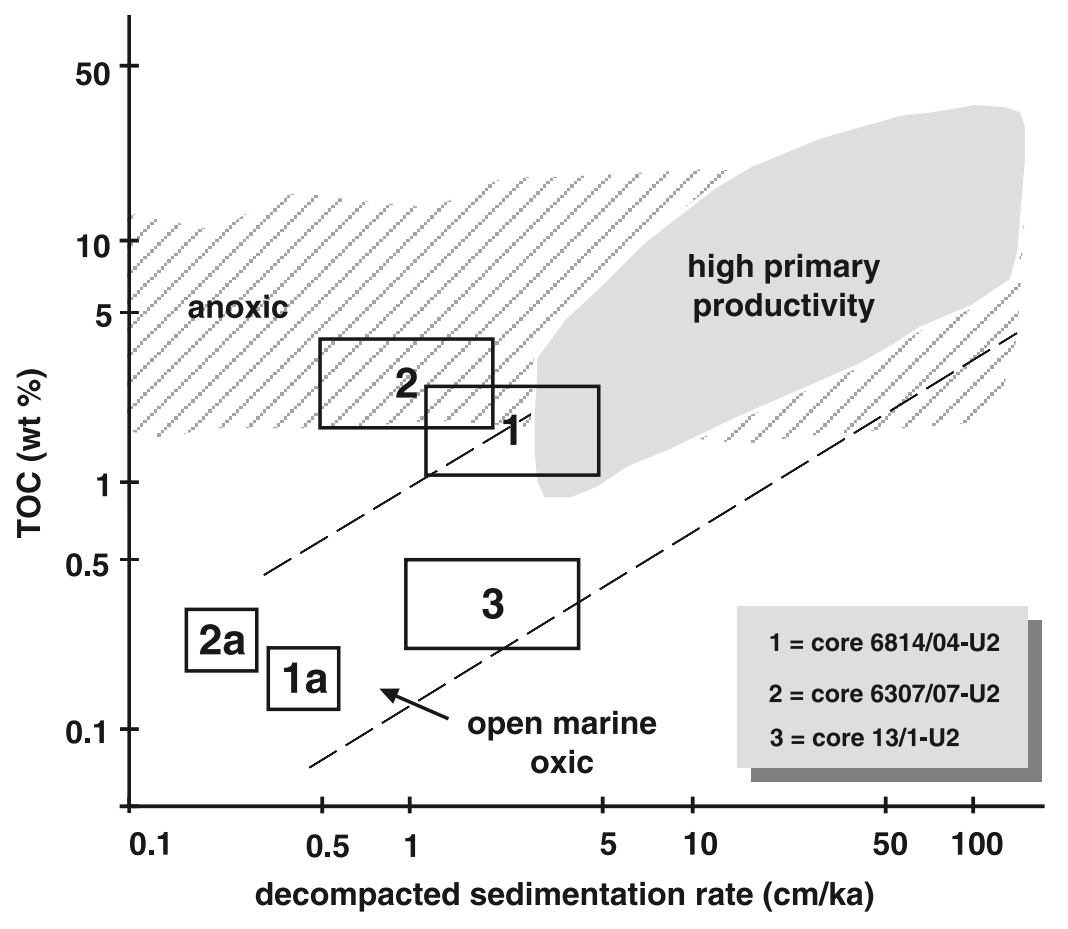

Figure 10. Relationship between (marine) organic carbon content and decompacted sedimentation rates (modified after Stein et al. [1986b, 1990]). Different fields of deposition (high productivity, anoxic, openmarine oxic) are based on results form Recent to Miocene sediments. Maximum sedimentation rates and minimum TOC data (and vice versa) were used to construct the open boxes which represent areas of potential deposition. The Volgian and Ryazanian sediments of the NGS (box 1 and 2) clearly show depositional conditions different to those in the SEP (box 3). Conditions in the NGS continuously changed to open-marine oxic in the Valanginian-Hauterivian (box 1a and 2a).

the Volgian. The black shales of the Volgian and Ryazanian of core 6307/07-U-02 (Figure 9b) plot below the "pyrite composition line" indicating limitations by reactive iron under oxygen-depleted conditions. There is a change along the line toward more oxic conditions, represented by the gray marl of the Valanginian (right flank), and the red marl of the succeeding Hauterivian (upper corner). The sediments of core 6814/04-U-02 are also characterized by distinct provinces. The general trend from more anoxic conditions in the Volgian to dysoxic conditions in the Ryazanian and oxic conditions in the Valanginian/Hauterivian is outlined in Figure 9c. The sediments of the Barremian, which follow a hiatus, plot in a different field (to the left) where the formation of pyrite is limited by the lack of labile organic matter (hydrogen-rich). These sediments are dominated by hydrogen-poor terrestrial OM, which seems to lessen the degree of decomposition by sulfate-reducing bacteria, and eventually decreases the availability of $\mathrm{H}_{2} \mathrm{~S}$ in the water column. This results in a decrease of pyrite framboids that crystallized in the water column (see pyrite size analysis above).

[25] The stratigraphic framework presented in the work of Mutterlose et al. [2003] reveals a very low sedimentation rate (SR) for all studied locations. The lack of dilution by clastic input is one of the prerequisites for accumulation of organic carbon-rich sediments. Low sedimentation rates may also indicate that high primary production was not the primary control on organic matter accumulation, at least not for the Norwegian-Greenland Seaway examples. Therefore we calculated initial (or decompacted) sedimentation rates $\left(\mathrm{SR}_{0}\right)$ to illustrate the relationship between marine organic carbon and sedimentation rate [after Stein et al., $1986,1990]$. We used a decompaction factor of $\times 2$ to $\times 5$ to account for the average porosity loss of clayey to silty sediments during diagenesis [e.g., Poelchau et al., 1997 and references therein]. Figure 10 shows the fields of potential deposition (open boxes) for each core. The Volgian to Ryazanian sediments of core 6307/07-U-02 (box 2) are hosted in the domain of anoxic depositional conditions, which is reflected by high TOC contents and a low sedimentation rates. There is an overlap with the field of potential deposition of core 6814/04-U-02 (box 1) which is characterized by lower TOC contents and somewhat higher sedimentation rates compared to core 6307/07-U-02. The figure displays a border situation for core 6814/04-U-02 between anoxic, open-marine oxic and high primary productivity conditions. This coincides with the foregoing discussion, and may actually represent suboxic to dysoxic conditions in the middle Volgian, and more moderately dysoxic conditions in the Ryazanian. The Valanginian and Hauterivian of the NGS basins (box 1a and 2a) are characterized by much lower TOC contents compared to the sedimentation rates; hence their fields of potential deposition fall in the "open-marine oxic" domain. The field of 
potential deposition of core 13/1-U-02 (box 3) is situated in the "open marine oxic" domain, and supports the interpretations from the foregoing discussion.

[26] We calculated the paleoproductivity for the blackshale sequences on the basis of estimated SR of 0.4$1.2 \mathrm{~cm} / 1000$ years for the early Volgian, and $1.2-1.9 \mathrm{~cm} /$ 1000 years for the late Volgian. For oxic environments we used the equation (1) after Müller and Suess [1979] and Stein et al. [1986b, 1990]:

$$
\mathrm{PP}=5.31 * \mathrm{C} * \mathrm{DBD}^{0.71} * \mathrm{LSR}^{0.07} * \mathrm{DEP}^{0.45},
$$

where PP is the primary productivity $\left(\mathrm{gC} / \mathrm{cm}^{2} / \mathrm{ka}\right), \mathrm{C}$ the (marine) organic carbon content, DBD is the dry bulk density $\left(\mathrm{g} / \mathrm{cm}^{3}\right)$, LSR the linear sedimentation rate $(\mathrm{cm} / \mathrm{ka})$, and DEP the water depth (m). We assumed $200 \mathrm{~m}$ as an average water depth for this location. For estimating paleoproductivity in anoxic environments we used equation (2) after Bralower and Thierstein [1987]:

$$
\mathrm{PP}=5 * \mathrm{C} * \mathrm{LSR} * \mathrm{DBD},
$$

where PP is the primary productivity $\left(\mathrm{gC} / \mathrm{cm}^{2} / \mathrm{ka}\right), \mathrm{C}$ the (marine) organic carbon content, DBD is the dry bulk density $\left(\mathrm{g} / \mathrm{cm}^{3}\right)$, and LSR the linear sedimentation rate $(\mathrm{cm} / \mathrm{ka})$. Paleoproductivity values for the anoxic NGS basins range from about 4 to $20 \mathrm{gC} / \mathrm{cm}^{2} / \mathrm{ka}$, which is similar to the sediments with the highest organic carbon contents in the modern Black Sea [e.g., Izdar et al., 1983]. Whereas the Southeastern Passage reveals about 30 to $40 \mathrm{gC} / \mathrm{cm}^{2} / \mathrm{ka}$ under oxic conditions, which is typical for open-marine environments [e.g., Stein et al., 1986].

[27] An increased supply of terrestrial OM seems to be the primary control on organic carbon accumulation in the Southeastern Passage, because here we have a clear positive correlation between the TOC content and the amount of vitrinite. This seems plausible since the deposition occurred in an open-marine oxic environment. The complete opposite is documented in the Norwegian-Greenland Seaway, where an increased supply of terrestrial OM is unlikely to have had a major control on the organic carbon accumulation.

\subsection{Paleoenvironmental Change Through Time}

[28] There are different indicators to believe that the sediments were deposited on the shelf not far off the paleoshore. First, the occurrence of well-preserved algae from fresh-water and brackish-water habitats along the NGS, such as Botryococcus and Tasmanites indicate the proximity to their sources. Some algae may possess an elevated buoyancy by emitting oil while they live (and so may have a larger distribution), but they will soon drop to the seafloor and become exposed to biochemical disintegration after their relatively short life cycle. Second, there are occasionally vitrinites, vascular bundles, and clasts of bituminous coal that reach up to $1.5 \mathrm{~mm}$ in size (often with a high length/width ratio). Under normal hydrodynamic conditions (average current speeds, etc.) such large particles have a very limited lateral distribution [e.g., Lückge et al., 1996; Taylor et al., 1998]. Third, the abundance of terrigenous liptinites, e.g., whole spores, along the NGS indicate the proximity to the land. In particular, high diversity in type suggests proximity to a larger variety of land-plant sources, which should decrease with increasing distance from land. In that course, high diversity in size indicates that these particles were also not transported over long distances by wind or water with respect to gravity fractionation.

[29] The increasing amount of detritus upward in the section, which is derived from land-plants indicates a reduction of the organic particle size through time. Consequently, the ratio between vitrinite and vitrodetrinite becomes generally smaller, although the relative amount of these macerals increases. Contemporaneously, the $\mathrm{Zr} / \mathrm{Al}$ ratio decreased (Figures 4 and 5) suggesting that the grain size of the nonriverine mineral fraction decreased, reflecting the reduced influence of aeolian input [e.g., Hinrichs et al., 2001]. Assuming fractionation by gravity as the primary mechanism for sorting particles, it seems that the distance between the core position and the coast line increased. However, in the northernmost location the change in the $\mathrm{Zr} / \mathrm{Al}$ ratio is much less, which is probably due to a special paleogeographic setting with a consistent input of windderived clastic material. Black shale formation is often associated with rapid transgression of epicontinental seas, particularly during the early stages [e.g., Sheridan, 1987]. A first transgression pulse may have already occurred in the early Volgian, which could have initialized the formation of black shales. Lateral adjacent coast-land including peat swamps may have been leached and increased the supply of nutrients and terrigenous organic matter to the sea margins, stimulating primary productivity that may have caused anoxia. But this theory is not supported by our results, because we illustrated that the black shale formation in the NGS was stimulated neither by a high sedimentation rate, a high terrigenous input, nor a high marine productivity. Deposition was likely hosted in an isolated anoxic basin with a stratified water column, probably covered by a permanent halocline (Figure 11). Primary production was low owing to limited nutrient supply, the lack of upwelling water masses, and perhaps low $\mathrm{Fe}^{2+}$ input from the continents [see Boyd et al., 2000]. The inflow of oxygenated water masses and the vertical circulation was inhibited, thus promoting the preservation of organic matter similar to the "stagnation model" [e.g., Brumsack, 1980; De Graciansky et al., 1984; Nijenhuis et al., 1999]. Therefore a transgression probably did not initiate, but rather "disturbed," the formation of black shales on a long-term scale. The hinterland became continuously flooded, vegetation withdrew, and the distance between the terrestrial sources and the depositional site increased. The amount of reworked terrestrial organic matter and the amount of detritus increased. Mutterlose et al. [2003] suggested a change from a more warm and humid climate in the Volgian to a more cool arid climate in the Valanginian/Hauterivian for the NorwegianGreenland Seaway, which may be supported by the ongoing decay of land-plant material. However, the momentous change was probably that oxygenated water masses started to enter the basins over ridges and sills, which probably destabilized the stratified water column by increased vertical circulation and eventually diminished the intensity of anoxia. This decreased the preservation of OM, and resulted 


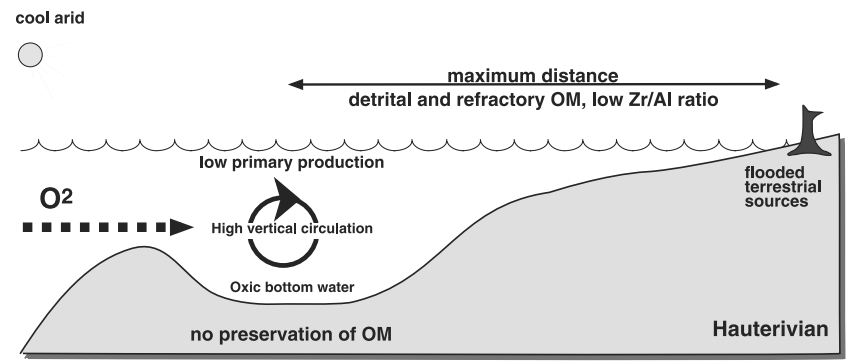

3. high-stand phase

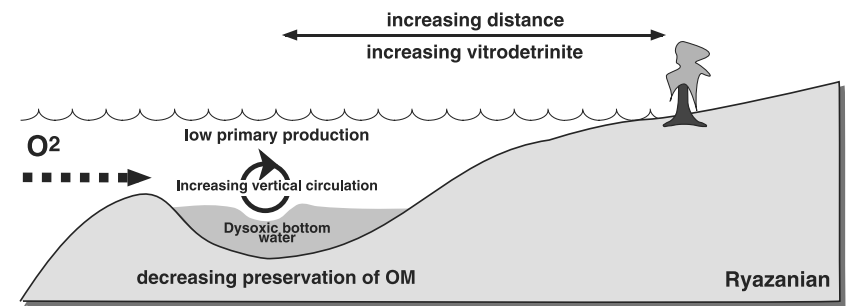

2. transgression phase

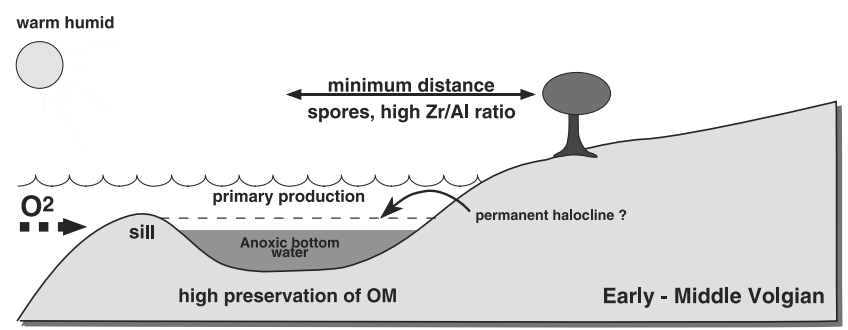

1. stagnation phase

Figure 11. Depositional model for the black shale formation in the eastern NGS. High preservation of OM is provided by oxygen deficiency, stratified water column, and short transport distances (vertical and lateral). Advanced transgression increases transport distance and water depth, and allow more oxygenated water masses to enter the basin. This probably results in a decrease of anoxia, the reestablishment of benthic activity, the decrease of lipidrich OM preservation, and eventually the termination of black shale formation.

in a fully oxygenated, more distal and sediment-starved basin in the Valanginian and Hauterivian. Even though primary production was probably enhanced during these conditions most of the marine organic matter was disintegrated before entering the sedimentary record.

\section{Conclusions}

[30] The latest Jurassic to earliest Cretaceous time slice provided favorable conditions for the formation of black shales in the eastern Norwegian-Greenland Seaway. In particular the Volgian is characterized by immature sedi- ments with high organic carbon contents and a fair to very good source rock generative potential.

[31] Maceral analysis, Rock-Eval data, and $\delta^{13} \mathrm{C}_{\mathrm{ORG}}$ data revealed a variable mixture of terrigenous and marine organic matter, suggesting that deposition occurred in a shelf environment. The abundance of terrigenous liptinite, particularly sporinite, and algae derived from freshwater and brackish habitats indicates the proximity to the paleoshore.

[32] Pyrite size distribution, TOC-Fe-S and sedimentation rate/organic carbon relationships suggest that black shale formation occurred under suboxic to anoxic bottom water conditions and a continuous long-term change to more open-marine oxic conditions. Changes from more hydrogen-rich organic matter in the early and middle Volgian to more "woody" and refractory organic matter in the Valanginian and Hauterivian is primarily a preservation effect controlled by the increase of bottom water oxygenation.

[33] The increasing amount of organic detritus derived from land-plants and the decreasing $\mathrm{Zr} / \mathrm{Al}$ ratio suggest that the core positions moved farther from the paleoshore, expanding the distance to the terrestrial sources. This may have occurred in terms of a transgression, probably caused by a sea-level rise.

[34] The sediments from the southeastern passage to the Tethys realm (core 13/1-U-02) were deposited under conditions unfavorable for the formation of petroleum source rocks. Deposition occurred in an open-marine oxic environment with low organic carbon contents and low sedimentation rates. Accumulation of organic carbon was controlled by the input of terrestrial, particularly "woody," organic matter.

\section{Appendix A}

[35] The plate shows a few microscopic photographs taken from cores 13/1-U-02, 6307/07-U-02, and 6814/04-U-02 with an AxioCam ${ }^{\circledR}$ digital color video camera during petrographic investigation. Figure A1 reflects the typical organic matter composition of the lower subunit A2 of core 13/1-U-02,

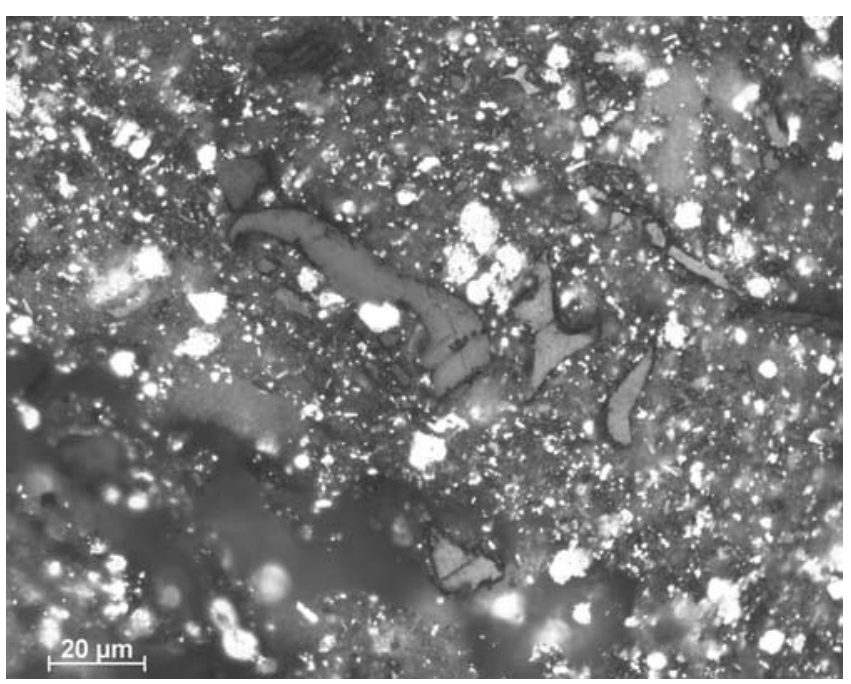

Figure A1. Typical OM composition of the lower subunit A2 of core13/1-U-02, dominated by terrestrial OM (207 mbsf), reflected white light, $200 \times$ magnification. 


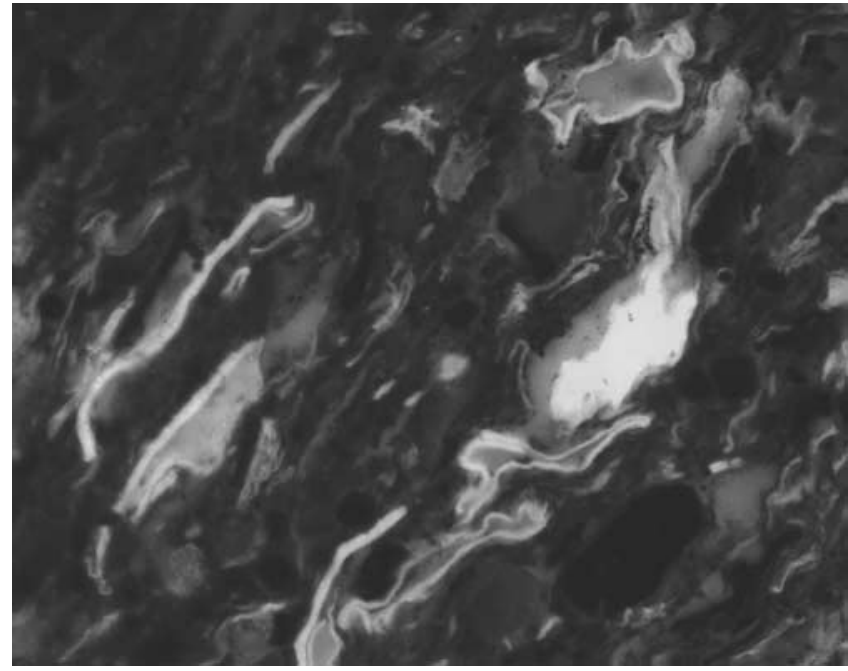

Figure A2. OM composition of the lower subunit $\mathrm{C}$ of core 13/1-U-02, reflecting the untypical abundance of lipidrich terrestrial OM, here spores (142 mbsf), blue light excitation, $500 \times$ magnification.

which is dominated by terrestrial OM. Angular vitrinites with "bogen" occur in assemblies that are patchily distributed in a pyritized, very fine-grained mineral matrix. TOC is about $0.2 \mathrm{wt} \%$ with a corresponding $\mathrm{HI}$ of about $10(\mathrm{mg}$ $\mathrm{HC} / \mathrm{g}$ TOC) (see Figure 3) (reflected white light, $200 \times$ magnification). A unique feature is documented in Figure A2, which shows the remarkable high abundance of terrestrial liptinite (here sporinite) in a depth of $142 \mathrm{~m}$ in the lower subunit $\mathrm{C}$ of core 13/1-U-02. This caused maximum TOC value of $1.7 \mathrm{wt} \%$ in the core and raised the $\mathrm{HI}$ to 110 (mgHC/g TOC) (see Figure 3, fluorescence light, $500 \times$ magnification). Figure A3 shows the typical organic

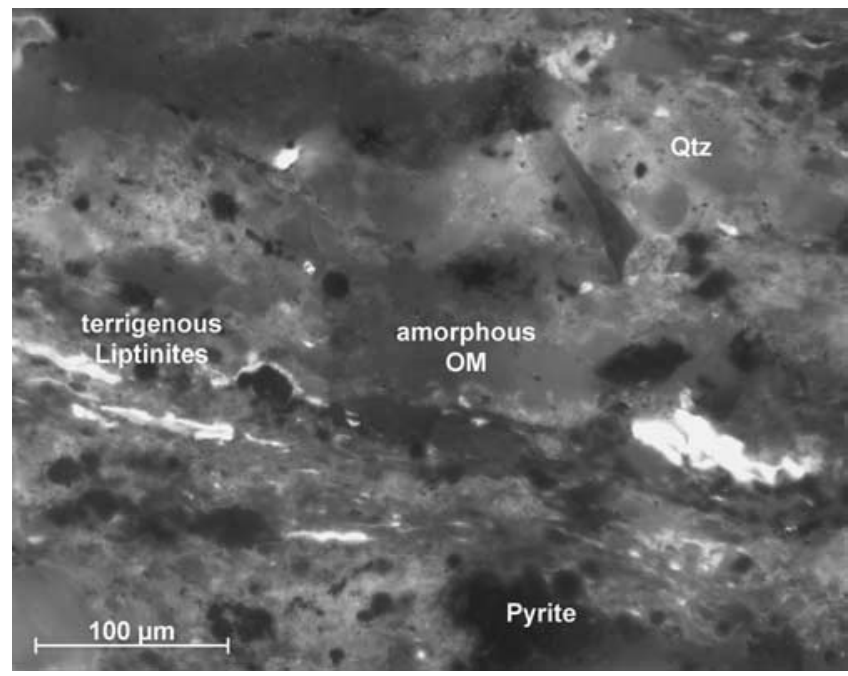

Figure A3. Typical OM composition of the Spekk formation of core 6307/07-U-02, showing OM derived from marine and lipid-rich terrestrial sources (80 mbsf), blue light excitation, $200 \times$ magnification.

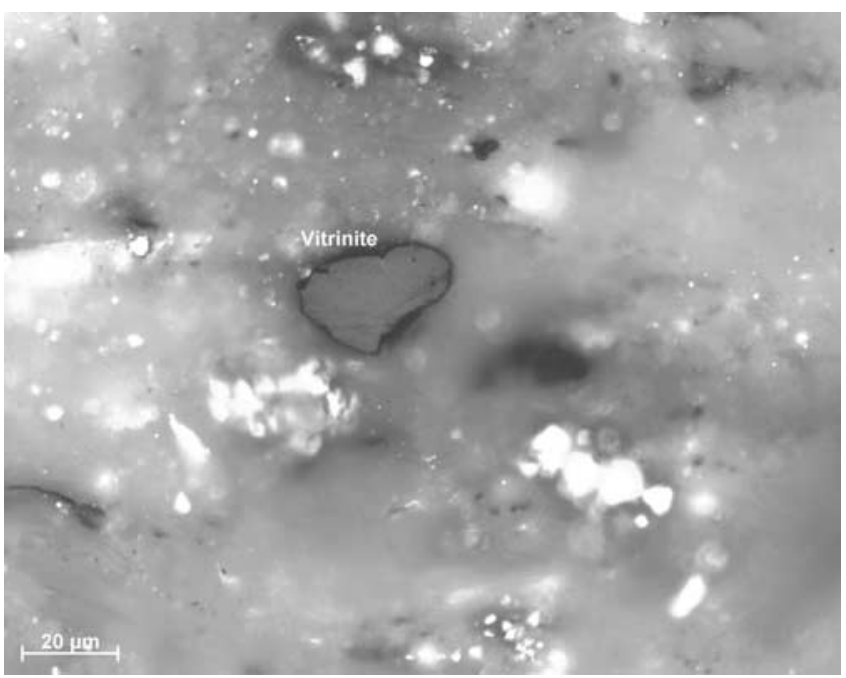

Figure A4. Typical OM composition of the lower Lange formation of core 6307/07-U-02, dominated by terrestrial OM (28 mbsf $)$, reflected white light, $500 \times$ magnification.

matter composition of the Spekk Formation of core 6307/07U-02, showing OM primarily derived from marine and lipidrich terrestrial sources at 80 meters depth. A high TOC of about $5 \mathrm{wt} \%$ corresponds to a high HI value of $500(\mathrm{mgHC} / \mathrm{g}$ TOC) (Figure 4). (blue light excitation, $200 \times$ magnification). The organic matter composition that predominates the lower Lange Formation in about $28 \mathrm{~m}$ depth is documented in Figure A4. TOC contents below 0.5 wt $\%$ and $\mathrm{HI}$ values below $100(\mathrm{mgHC} / \mathrm{g}$ TOC) are reflected in the scarcity of organic particles and the high percentage of refractory material derived from land-plant sources. The vitrinite particle in the center is of low maturity but relatively small and well rounded. The matrix is dull and translucent due to high

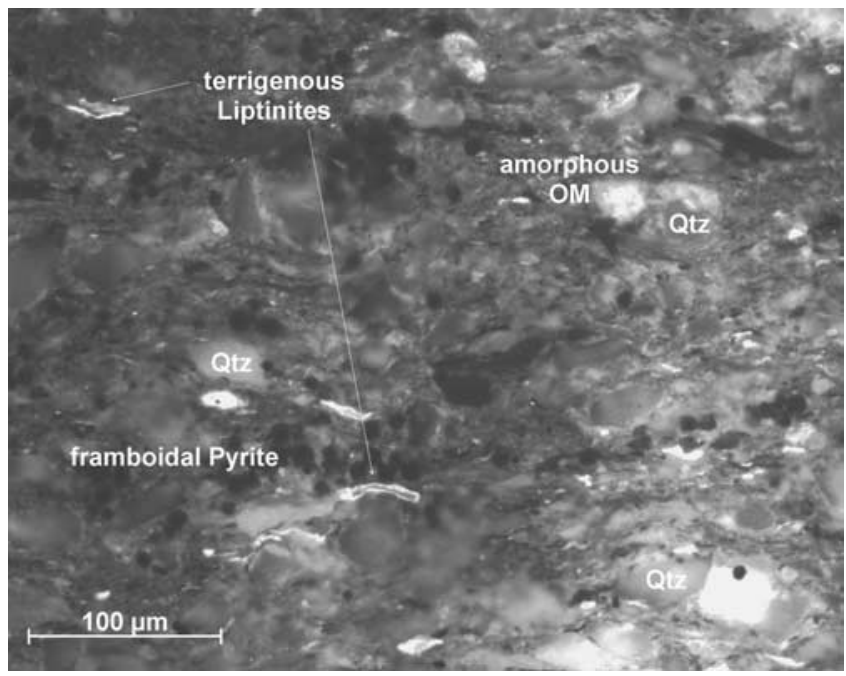

Figure A5. Typical OM composition of the Hekkingen formation of core 6814/04-U-02, showing OM derived from marine and lipid-rich terrestrial OM (136 mbsf), blue light excitation, $200 \times$ magnification. 


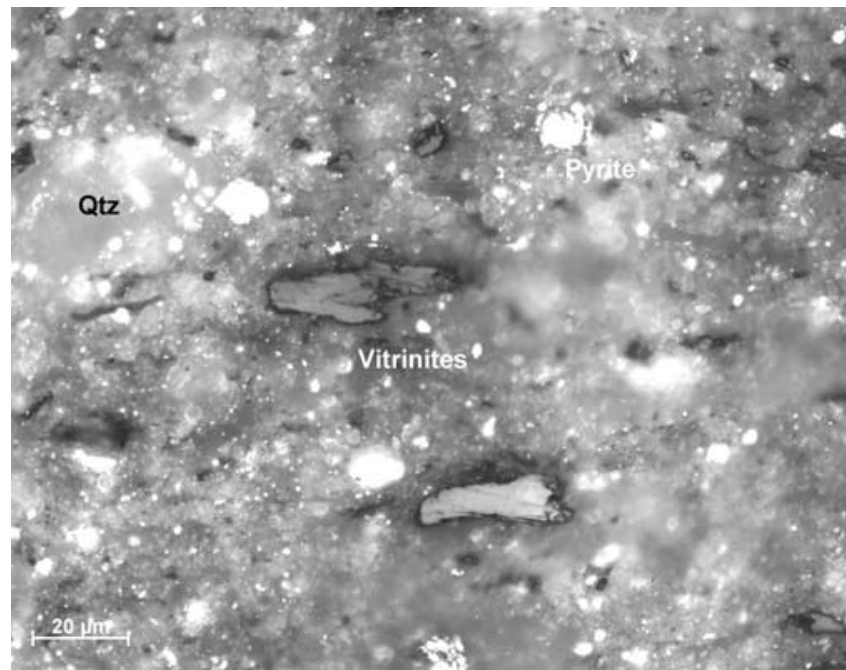

Figure A6. Typical OM composition of the Kolje Formation of core $6814 / 04-\mathrm{U}-02$, dominated by terrestrial $\mathrm{OM}(11 \mathrm{mbsf})$, reflected white light, $500 \times$ magnification. quartz abundance, pyrite is allochthonous and/or pore water generated (reflected white light, $500 \times$ magnification). The most organic carbon-rich sequences of the Hekkingen formation of core 6814/04-U-02 are best represented by Figure A5 taken at 136 meters depth. High TOC contents of about $4.5 \mathrm{wt} \%$ correspond to a but moderate preservation, indicated by HI of about 250 (mgHC/g TOC). Two thirds of the organic matter has derived from terrestrial and one third from marine sources (blue light excitation, $200 \times$ magnification). Figure A6 shows the typical organic matter composition of the Kolje Formation of core 6814/04-U-02 (Barremian). Although strictly dominated by terrestrial OM, as reflected by $\mathrm{HI}$ values $\leq 80$, TOC values of about $2.5 \mathrm{wt} \%$ reflect good preservation, probably by other processes than stagnation (reflected white light, $500 \times$ magnification).

[36] Acknowledgments. Financial support by the Deutsche Forschungsgemeinschaft (grant STE 412/13-1 and BR 775/10-1) is gratefully acknowledged. SINTEF Petroleum Research (Trondheim) kindly provided drilling core material and gave access to unpublished data. We thank $\mathrm{U}$. Wand and S. Klein for technical assistance. We appreciate the critical comments of T. Wagner, U. Mann, J. Matthiessen, H. M. Weiss, M. Smelror, and R. Littke on this manuscript.

\section{References}

Århus, N., The transition from deposition of condensed carbonates to dark claystones in the Lower Cretaceous succession of the southwestern Barents Sea, Nor. Geol. Tidsskr., 71, 259-263, 1991

Århus, N., T. Bugge, G. Elvebakk, V. Fjerdingstad, T. L. Leith, A. Mørk, H. Rendall, O. Skarbø, and H. M. Weiss, Report of Shallow drilling Elf Aquitaine, Norsk Hydro, Statoil Barents Sea, 50 pp., IKU, Trondheim, 1987.

Arthur, M. A., W. E. Dean, and G. E. Claypool, Anomalous ${ }^{13} \mathrm{C}$ enrichment in modern marine organic carbon, Nature, 315, 216-218, 1985.

Arthur, M. A., S. O. Schlanger, and H. C. Jenkyns, The Cenomanian-Turonian oceanic anoxic event, II: Palaeoceanographic controls on organic-matter production and preservation, Geol. Soc. Spec. Publ., 26, 401-420, 1987.

Berner, R. A., Sedimentary pyrite formation: An update, Geochim. Cosmochim. Acta, 48, 605615, 1984.

Berner, R. A., and R. Raiswell, Burial of organic carbon and pyrite sulfur in sediments over Phanerozoic time: A new theory, Geochim. Cosmochim. Acta, 47, 855-862, 1983.

Boyd, P. W., et al., A mesoscale phytoplankton bloom in the polar Southern Ocean stimulated by iron fertilization, Nature, 407, 695-702, 2000.

Bralower, T. J., and H. R. Thierstein, Organic carbon accumulation rates in Holocene and mid-Cretaceous sediments: Paleoceanographic significance, Geol. Soc. Spec. Publ., 26, 345369,1987

Brekke, H. D., S. Dahlgren, B. Nyland, and C. Magnus, The prospectivity of the Vøring and Møre basins on the Norwegian Sea continental margin, in Petroleum Geology of Northwest Europe: Proceedings of the 5th Conference edited by A. J. Fleet and S. A. R. Boldy, pp. 261274, Geol. Soc., London, 1999.

Brumsack, H. J., Geochemistry of Cretaceous black shales from the Atlantic Ocean, Chem. Geol., 31, 1-25, 1980.

Brumsack, H. J., Rezente $\mathrm{C}_{\text {org }}$-reiche Sedimente als Schlüssel zum Verständnis fossiler
Schwarzschiefer, Habilitationsschrift, Univ of Göttingen, Göttingen, 1988.

Bugge, T., et al., Report of Shallow Drilling Barents Sea 1988, 309 pp., IKU, Trondheim, 1989.

Bugge, T., G. Elvebakk, S. Fanavoll, G. Mangerud, M. Smelror, H. M. Weiss, J. Gjelberg, S. E. Kristensen, and K. Nilsen, Shallow stratigraphic drilling applied in hydrocarbon exploration of the Nordkapp Basin, Barents Sea, Mar. Petrol. Geol., 19, 13-37, 2002.

Calvert, S. E., and T. F. Pedersen, Organic carbon accumulation and preservation in marine sediments: How important is anoxia?, in Organic Matter: Productivity, Accumulation, and Preservation in Recent and Ancient Sediments, edited by J. K. Whelan and J. W. Farrington, 533 pp., Columbia Univ. Press, New York, 1992.

Caplan, M. L., and R. M. Bustin, Paleoceanographic controls on geochemical characteristics of organic-rich Exshaw mudrocks: Role of enhanced primary production, Organic Geochem., 30, 161-188, 1998.

Coplen, T. B., Reporting of stable carbon, hydrogen, and oxygen isotopic abundance, in IAEATECDOC-825, Reference and Intercomparison Materials for Stable Isotopes of Light Elements, pp. 31-34, Int. At. Energy Assoc., Vienna, 1995.

Cornford, C., P. Gardner, and C. Burgess, Geochemical truths in large data sets, I: Geochemical screening data, Organic Geochem., 29(1-3), 519-530, 1998.

Dean, W. E., and M. A. Arthur, Iron-sulfur-carbon relationships in organic-carbon-rich sequences: Cretaceous western interior seaway, Am. J. Sci., 289, 708-743, 1989.

Dean, W. E., M. A. Arthur, and G. E. Claypool, Depletion of ${ }^{13} \mathrm{C}$ in Cretaceous marine organic matter: Source, diagenetic, or environmental signal?, Mar. Geol., 70, 119-157, 1986.

De Graciansky, P. C., G. Deroo, J. P. Herbin, L. Montadert, C. Müller, A. Schaaf, and J. Sigal, Oceanwide stagnation episode in the late Cretaceous, Nature, 308, 346-349, 1984
De Graciansky, P. C., E. Brosse, G. Deroo, J.-P. Herbin, L. Montadert, C. Müller, J. Sigal, and A. Schaaf, Organic-rich sediments and palaeoenvironmetal reconstructions of the Cretaceous North Atlantic, Geol. Soc. Spec. Publ., 26, 317-344, 1987.

Demaison, G. J., and G. T. Moore, Anoxic environments and oil source bed genesis, Organic Geochem., 2, 9-31, 1980 .

Doré, A. G., The structural foundation and evolution of Mesozoic seaways between Europe and the Arctic, Palaeogeogr. Palaeoclimatol. Palaeoecol., 87, 441-492, 1991.

Engleman, E. E., L. L. Jackson, and D. R. Norton, Determination of carbonate in geological materials by coulometric titration, Chem. Geol., 53, 125-128, 1985.

Espitalié, J., J. L. Laporte, M. Madec, F. Marquis, P. Leplat, J. Paulet, and A. Boutefeu, Méthode rapide de characterisation des rochesmere, de leur potential petrolier et de leur degre d'evolution, Rev. Inst. Fr. Pet., 32, 23-42, 1977.

France-Lanord, C., and L. A. Derry, $\delta^{13} \mathrm{C}$ of organic carbon in the Bengal Fan: Source evolution and transport of $\mathrm{C} 3$ and $\mathrm{C} 4$ plant carbon to marine sediments, Geochim. Cosmochim. Acta, 58(21), 4809-4814, 1994.

Fry, B., W. Brand, F. J. Mersch, K. Tholke, and R. Garritt, Automated analysis system for coupled $\delta^{13} \mathrm{C}$ and $\delta^{15} \mathrm{~N}$ measurements, Anal. Chem., 64, 288-291, 1992.

Hallam, A., Mesozoic organic-rich shales, Geol. Soc. Spec. Publ., 26, 251-261, 1987.

Hansen, J. W., et al., Shallow Drilling Nordland VI and VII 1991, 390 pp., IKU, Trondheim, 1991.

Haq, B. U., J. Hardenbol, and P. R. Vail, Mesozoic and Cenozoic chronostratigraphy and cycles of sea-level change, in Sea Level Changes: An Integrated Approach, SEPM Spec. Publ., vol. 42, edited by C. K. Wilgus et al., pp. 71-108, SEPM, location, 1988.

Hardenbol, J., J. Thierry, M. B. Farley, T. Jacquin, P. C. de Graciansky, and P. R. Vail, Mesozoic and Cenozoic sequence chronostratigraphic 
framework of European basins, Soc. Sediment. Geol. Spec. Publ., 60, 7-14, 1998.

Hay, W. W., et al., Alternative global Cretaceous paleogeography, in Evolution of the Cretaceous Ocean-Climate System, edited by E. Barrera and C. Johnson, pp. 1-47, Geol. Soc. Am., Boulder, Colo., 1999.

Hinrichs, J., B. Schnetger, H. Schale, and H.-J. Brumsack, A high resolution study of NE Atlantic sediments at station Bengal: Geochemistry and early diagenesis of Heinrich layers, Mar. Geol., 177, 79-92, 2001.

Hofmann, P., W. Ricken, L. Schwark, and D. Leythaeuser, Carbon-sulfur-iron relationships and $\delta^{13} \mathrm{C}$ of organic matter for late Albian sedimentary rocks from the North Atlantic Ocean: Paleoceanographic implications, Palaeoceanogr. Palaeoclimatol. Palaeoecol., $163,97-113,2000$

Horsfield, B., et al., Organic geochemistry of freshwater and alkaline lacustrine sediments in the Green River Formation of the Washakie Basin, Wyoming, USA, Organic Geochem., 22, 415-440, 1994.

Huffman, E. W. D., Jr., Performances on a new automatic carbon dioxide coulometer, Microchem. J., 22, 567-573, 1977.

Izdar, E., T. Konuk, V. Ittekkot, S. Kempe, and E. T. Degens, Particle flux in the Black Sea: Nature of the organic matter, in Particle Flux in the Ocean, vol. 62, edited by E. T. Degens et al., pp. 1-18, Mitt. des Geol. Paläontol. Inst. der Univ. Hamburg, Hamburg, 1983.

Langford, F. F., and M. M. Blanc-Valleron, Interpreting rock-eval-pyrolysis data using graphs of pyrolysable hydrocarbons vs. total organic carbon, AAPG Bull., 74, 799-804, 1990.

Langrock, U., and R. Stein, Organic matter preservation and paleoenvironmental implications for Lower Cretaceous marine sapropels from the Norwegian and Barents Sea shelf, abstract presented at the EUG XI Conference, J. Conf. Abstr., 6(1), 196-197, 2001.

Langrock, U., R. Stein, M. Lipinski, and H.-J. Brumsack, Paleoenvironment and sea-level change in the early Cretaceous Barents SeaImplications from near-shore marine sapropels, Geo. Mar. Lett., in press, 2003.

Larson, R. L., Geological consequences of superplumes, Geology, 19, 963-966, 1991

Leith, T. L., et al., Mesozoic hydrocarbon sourcerocks of the Arctic region, in Arctic Geology and Petroleum Potential, Norw. Petrol. Soc. Spec. Publ., vol. 2, edited by T. O. Vorren et al., pp. 1-25, 1992.

Lippard, S., and K. Rokoengen, Shallow drilling Farsund Subbasin 1988/89: Bedrock mapping and evaluation of potential coring sites, Rep. 21.3460.00/01.89, 47 pp., IKU, Trondheim, 1989.

Lückge, A. B., M. Lallier-Vergès, and R. Littke, Comparative study of organic matter preservation in immature sediments along the continental margins of Peru and Oman, part I: Results of petrographical and bulk geochemical data, Organic Geochem., 24(4), 437-451, 1996.

Lüniger, G., and L. Schwark, Characterization of sedimentary organic matter by bulk and molecular geochemical proxies: An example from an Oligocene maar-type Lake Enspel, Germany, Sediment. Geol., 148(1-2), 275-288, 2002.

Meyers, P. A., Organic geochemical proxies of paleoceanographic, paleolimnologic, and paleoclimatic processes, Organic Geochem., 27, 213-250, 1997

Müller, P. J., and E. Suess, Productivity, sedimentation rate and sedimentary organic carbon in the oceans, 1: Organic carbon preservation, Deep Sea Res., Part I, 26, 1347-1362, 1979.

Mutterlose, J., et al., The Greenland-Norwegian Seaway: A key area for understanding Late Jurassic to Early Cretaceous paleoenvironments, Paleoceanography, 18(1), 1010 , doi:10.1029/2001PA000625, 2003

Nijenhuis, I. A., H.-J. Bosch, J. S. Sinninghe Damsté, H.-J. Brumsack, and G. J. De Lange, Organic matter and trace element rich sapropels and black shales: A geochemical comparison, Earth Planet. Sci. Lett., 169, 277-290, 1999.

Onstad, D. G., D. E. Canfield, P. D. Quay, and J. Hedges, Sources of particulate organic matter in rivers from the continental USA: Lignin phenol and stable isotope composition, Geochim Cosmochim. Acta, 64(20), 3539-3546, 2000.

Pedersen, T. F., and S. E. Calvert, Anoxia versus productivity: What controls the formation of organic carbon-rich sediments and sedimentary rocks?, AAPG Bull., 74(4), 454-466, 1990.

Peters, K. E., Guidelines for evaluating petroleum source rock using programmed pyrolysis, AAPG Bull., 70(3), 318-329, 1986.

Poelchau, H. S., D. R. Baker, T. Hantschel, B. Horsfield, and B. Wygrala, Basin simulation and the design of the conceptual basin model, in Petroleum and Basin Evolution, edited by D. H. Welte et al., pp. 3-70, Springer-Verlag, New York, 1997.

Rau, G. H., M. A. Arthur, and W. E. Dean, 15N/ $14 \mathrm{~N}$ variations in Cretaceous Atlantic sedimentary sequences: Implications for past changes in marine nitrogen biogeochemistry, Earth Planet. Sci. Lett., 82, 269-279, 1987.

Röhl, H.-J., A. Schmid-Röhl, W. Oschmann, A. Frimmel, and L. Schwark, The Posidonia Shale (Lower Toarcian) of SW Germany: An oxygen-depleted ecosystem controlled by sea level and paleoclimate, Palaeogeogr. Paleoclimatol. Paleoecol., 165, 27-52, 2001.

Rokoengen, K., S. Lippard, R. Morgensen, and L. Rise, Nearshore bedrock mapping $62^{\circ}$ $57^{\circ} 30^{\prime} \mathrm{N}$, Rep. $24.1486 / 01 / 88,62$ pp., IKU, Trondheim, 1988

Routh, J., T. J. McDonald, and E. L. Grossman, Sedimentary organic matter sources and depositional environment in the Yegua formation (Brazos County, Texas), Organic Geochem. 30, 1437-1453, 1999.

Saelen, G., R. V. Tyson, N. Telnaes, and M. R. Talbot, Contrasting watermass conditions during deposition of the Whitby Mudstone (Lowe Jurassic) and Kimmeridge Clay (Upper Jurassic) formations, UK, Palaeogeogr. Palaeoclimatol. Palaeoecol., 163, 163-196, 2000.

Schlanger, S. O., and H. C. Jenkyns, Cretaceous oceanic anoxic events: Causes and consequences, Geol. Mijnbouw, 55, 179-184, 1976. Schlanger, S. O., M. A. Arthur, H. C. Jenkyns, and P. A. Scholle, The Cenomanian-Turonian oceanic anoxic event, I: Stratigraphy and distribution of organic carbon-rich beds and the marine $\delta^{13} \mathrm{C}$ excursion, Geol. Soc. Spec. Publ., 26, 371-399, 1987

Schouten, S., M. Schoell, W. I. C. Rijpstra, J. S. Sinninghe Damsté, and J. W. De Leeuw, A molecular stable carbon isotope study of organic matter in immature Miocene Monterey sediments, Pismo basin, Geochim. Cosmochim. Acta, 61(10), 2065-2082, 1997.

Sheridan, R. E., Pulsation tectonics as the control of North Atlantic palaeoceanography, Geol. Soc. Spec. Publ., 21, 255-275, 1987.

Sinninghe Damsté, J. S., and J. Köster, An euxinic southern North Atlantic Ocean during the Cenomanian/Turonian oceanic anoxic event, Earth Planet. Sci. Lett., 158, 165-173, 1998.
Smelror, M., A. Mørk, E. Monteil, D. Rutledge, and H. Leereveld, The Klippfisk Formation-A new lithostratigraphic unit of Lower Cretaceous platform carbonates on the Western Barents Shelf, Polar Res., 17, 181-202, 1998.

Smelror, M., A. Mørk, M. B. E. Mørk, H. M. Weiss, and H. Løseth, Middle Jurassic-Lowe Cretaceous transgressive-regressive sequences and facies distribution off Troms, northern Norway, in Sedimentary Environments Offshore Norway-Palaeozoic to Recent, NPF Spec. Publ., vol. 10, edited by O. J. Martinsen and T. Dreyer, pp. 211-232, Norw. Petrol. Soc., Oslo, 2001a.

Smelror, M., H. Dypvik, and A. Mork, Cretaceous boundary beds of the Barents Sea possibly induced by the Mjolnir meteorite impact, in Geological and Biological Effects of Impact Events: Impact Studies, edited by E. Buffetaut and C. Koeberl, pp. 69-82, Springer-Verlag, New York, 2001b.

Stein, R., Organic carbon content/sedimentation rate relationship and its paleoenvironmental significance for marine sediments, Geo. Mar. Lett., 10, 37-44, 1990.

Stein, R., J. Rullkötter, and D. H. Welte, Accumulation of organic-carbon-rich sediments in the Late Jurassic and Cretaceous Atlantic OceanA synthesis, Chem. Geol., 56, 1-32, 1986.

Taylor, G. H., M. Teichmüller, A. Davies, C. F. K. Diessel, R. Littke, and P. Robert (Eds.), Organic Petrology, 704 pp., Gebrüder Bornträger, Berlin, 1998.

Tribovillard, N., A. Bialkowski, R. V. Tyson, E. Lallier-Vergès, and J.-F. Deconinck, Organic facies variation in the late Kimmeridgian of the Boulonnais area (northernmost France), Mar. Petrol. Geol., 18, 371-389, 2001.

Twichell, S. C., P. A. Meyers, and L. DiesterHaass, Significance of high $\mathrm{C} / \mathrm{N}$ ratios in organic-carbon-rich Neogene sediments under the Beguela Current upwelling system, Organic Geochem., 33, 715-722, 2002

Van de Schootbrugge, B., K. B. Föllmi, L. G. Bulot, and S. J. Burns, Paleoceanographic changes during the early Cretaceous (Valanginian-Hauterivian): Evidence from oxygen and carbon stable isotopes, Earth Planet. Sci. Lett., $181,15-31,2000$

Wilkin, R. T., H. L. Barnes, and S. L. Brantley, The size distribution of framboidal pyrite in modern sediments: An indicator of redox conditions, Geochim. Cosmochim. Acta, 60 3897-3912, 1996

Wilkin, R. T., M. A. Arthur, and W. E. Dean, History of water-column anoxia in the Black Sea indicated by pyrite framboid size distributions, Earth Planet. Sci. Lett., 148, 517-525, 1997.

Worsley, D., R. Johansen, and S. E. Kristensen, The Mesozoic and Cenozoic succession of Tromsøflaket, Norw. Petr. Direct. Bull., 4, 42-65, 1988.

Ziegler, P. A., (Ed.), Evolution of the ArcticNorth Atlantic and the Western Tethys, AAPG Mem., vol. 43, 198 pp., Am. Assoc. of Petrol. Geol., Tulsa, Okla., 1988.

H.-J. Brumsack and M. Lipinski, Institute of Chemistry and Biology of the Marine Environment (ICBM), Carl von Ossietzky University, D26111 Oldenburg, Germany. (h.brumsack@ icbm.de; m.lipinski@icbm.de)

U. Langrock and R. Stein, Alfred Wegener Institute for Polar and Marine Research, Columbusstrasse, D-27568 Bremerhaven, Germany (ulangrock@awi-bremerhaven.de; rstein@awibremerhaven.de) 